Including: Social Work, Humanitary Health Intervention, Nursing, Missionary Work

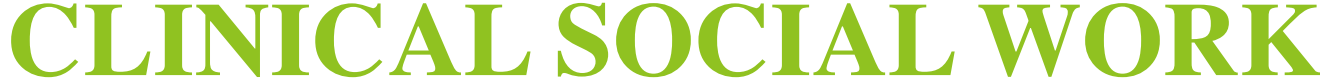

\title{
AND HEALTH INTERVENTION
}

international

scientific

group

of applied

preventive

medicine I - GAP

vienna,

austria

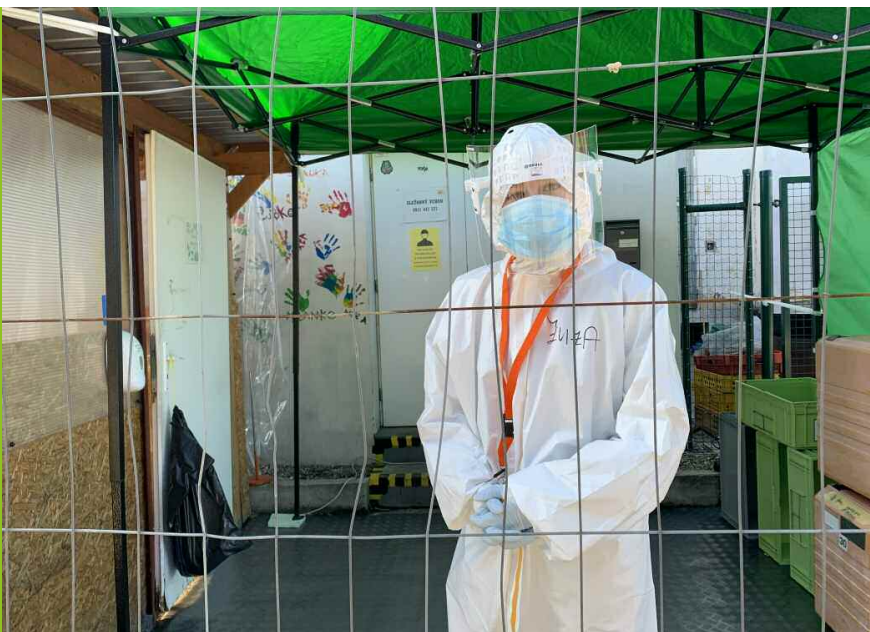

Author: Michael Olah

\section{Social Ethical and Health Consequences of Covid 19 and HIV Pandemics \\ Original Articles}

$\checkmark$ EDITORIAL: REDUCING COVID-19 INFECTION EXPOSURES: AUTONOMY VERSUS NON-MALIFICENCE

$\checkmark$ THE EMPHASIS ON THE RELEVANT NEEDS OF THE PARENTS OF EXTREMELY PREMATURE INFANTS WITH SPECIAL REGARD TO THE IMPACT OF COVID-19

$\checkmark$ HIV MOBILE CLINIC AS A PART OF THE COMPREHENSIVE SOCIAL AND PUBLIC HEALTH PROGRAM IN THE MALINDI COASTAL AREA

$\checkmark$ COVID-19 HAS ONLY TEMPORARILY INTERRUPTED SOCIAL AND HEALTH SERVICES IN RURAL ALBANIA IN 2020 $\checkmark$ ST. PHILIPPE RESCUE CENTER IN AN AREA OF HIGH PREVALENCE OF HIV INFECTION IN KISUMU AND STREET WORK FOR STREET BOYS IN NAIROBI

$\checkmark$ EDUCATIONAL SOCIAL AND HEALTH JOINT BICOLORAL WORLD \& SEU PROGRAM FOR HIV POSITIVE CAMBODIAN CHILDREN - RESEARCH NOTE

$\checkmark$ COVID-19 PANDEMICS IN UGANDA LED TO CESSATION OF THE COMPREHENSIVE HIV PROGRAM IN RURAL AREAS OF NORTH LAKE VICTORIA REGION

$\checkmark$ COMPARISON OF THE SPECTRUM OF OUTPATIENT VISITS BEFORE AND AFTER FIRE IN THE MORIA CAMP AFTER ARRIVAL OF COVID-19 POSITIVE REFUGEES

$\checkmark$ UNDERSTANDING PAKHTUN WOMAN'S VULNERABILITY IN NEGOTIATION WITH THEIR HUSBANDS FOR HIV/AIDS SCREENING

ONE MONTH OR REAL LIFE IN A SINGLE CLINIC NEAR THE SLUM AREA IN MUKURU URBAN SETTING IN THE TIME AFTER COVID-19 EPIDEMIC IN KENYA

$\checkmark$ AN ANALYSIS OF ANTHROPOMETRIC MEASUREMENTS OF CHILDREN ENROLLED IN PROGRAMS FOR MANAGING ACUTE MALNUTRITION, IN KWALE COUNTY, KENYA $\checkmark$ HIGHLANDS MALARIA IS COMMON BUT HIV VERY RARE IN RURAL AREAS OF BURUNDI 2,000 METERS ABOVE SEA LEVEL (SHORT COMMUNICATION)

$\checkmark$ APPLICATION OF POINT-OF-CARE TESTING (POCT) IN DIAGNOSTICS OF INFLUENZA DURING COVID-19 PANDEMIC IN ELDERLY HOSPITALIZED PEOPLE (SHORT COMMUNICATION)

$\checkmark$ ALLEVIATION OF REFUGEE CRISIS IN LEBANON THROUGH HUMANITARIAN AID PROJECTS OF SLOVAK DEVELOPMENT ORGANIZATIONS IN THE ERA OF COVID-19 PANDEMIC

$\checkmark$ FINANCIAL LITERACY AS ONE OF THE PROFESSIONAL COMPETENCIES OF SOCIAL WORKERS TO PREVENT OR SOLVE SOCIO-ECONOMIC PROBLEMS 


\section{Editors}

\section{Editor-in-Chief:}

Peter G. Fedor-Freybergh, MD, Dr. Phil, Ph.D, DSc,

Dr.h.c. mult. (Vienna, AT)

\section{Deputy Chief Editors:}

Prof. Dr. Dr. med. Clauss Muss, PhD

(I-GAP Zurich, CH)

\section{Editorial board and reviewers:}

Dr. Andrea Shahum, MD (University of North

Carolina at Chapel Hill School of Medicine, USA)

Dr. Vlastimil Kozon, PhD.

(Allgemeines Krankenhaus - Medizinischer

Universitätscampus, Vienna, AT)

Dr. Daniel J. West, Jr. Ph.D, FACHE

(University of Scranton, Department of Health

Administration and Human Resources, USA)

Dr. Stephen J. Szydlowski, MBA, MHA, DHA

(University of Scranton school of education, USA)

Dr. zw. dr hab. Pawel S. Czarnecki, Ph.D.

(Rector of the Warsaw Management University, PL)

Dr. Michael Costello, MA, MBA, J.D.

(University of Scranton school of education, USA)

Dr. Roberto Cauda, Ph.D.

(Institute of Infectious Diseases, Catholic University of the Sacred Heart, Rome, IT)

Dr. Tadeusz Bak, PhD.

(Instytut Ekonomii i Zarządzania PWSTE

Jarosław, PL)
Dr. Daria Kimuli, Ph.D.

(Catholic university of Eastern Africa, Nairobi, KE)

Dr. Gabriela Lezcano, Ph.D.

(University of California, San Francisco, USA)

Dr. Jirina Kafkova, Ph.D. (MSF, Freetown, SL)

Prof. Dr. Arab Naz, Ph.D.

(University of Malakand Chakdara Khyber

Pakhtunkhwa PK)

Dr. Vitalis Okoth Odero, Ph.D.

(St. Philippe Neri Schools Joshka, KE)

Dr. Johnson Nzau Mavole, Ph.D.

(Catholic university of Eastern Africa, Nairobi, KE)

Prof. Dr. Selvaraj Subramanian, Ph.D.

(SAAaRMM, Kuala Lumpur, MY)

Dr. hab. Zofia Szarota, Ph.D.

(Pedagogical University of Cracow, PL)

\section{Commisioning and language editor:}

Prof. Dr. John Turner (Amsterdam, NL)

Whole-Self@quicknet.nl

\section{Submit manuscript:}

cswjournal@gmail.com

\section{Photo:}

Michael Olah: Shelter for homeless people in central europe hit by a pandemic.

\section{Visiting Editors}

Michael M. Costello, Scranton

International Gesellschaft für angewandte

Präventionsmedizin i-gap e.V.

(International Society of Applied Preventive

Midicine i-gap)

Währinger Str. 63 A-1090

Vienna, Austria

Tel. : +49 - 176 - 24215020

Fax : +43 / 1408313129

Mail : office@i-gap.org

Web : www.i-gap.org

\section{Impact factor}

1. november 2019

1,21

Subscription rates 2021, Vol. 12, No.1

Open Access Journal

Additional Information on Internet:

www.clinicalsocialwork.eu 


\section{Table of Contents}

\section{Original Articles}

Michael M. Costello

Editorial: Reducing COVID-19 Infection Exposures: Autonomy

versus Non-Malificence

Jan Masan, Kamil Kolejak, Mariana Hamarova

The Emphasis on the Relevant Needs of the Parents of Extremely

Premature Infants with Special Regard to the Impact of COVID-19

James Kazungu Katana, Jarmila Holkova, Juraj Benca, Igor Kmit, Zlata Ondrusova,

Peter Laca, Dana Giertliova, Tomas Rusnak, Eva Horvathova, Martina Utesena,

Vladimir Krcmery, Maria Hardy

HIV Mobile Clinic as a Part of the Comprehensive Social and Public Health Program in the Malindi Coastal Area

Monika Palockova, Stanislava Chovancova, Daniela Sugarova, Eva Zdilova, Ferdinand Sasvary, Maria Sasvary, Daniela Barkasi, Monika Gulasova, Igor Kmit, Michal Olah, Rastislav Hochman, Eva Haluskova, Martina Partelova, Emanuel Trichard Covid-19 has only Temporarily Interrupted Social and Health Services in rural Albania in 2020

Thomas Rusnak, Zlata Ondrusova, Michal Olah, Pavel Bryndzak, Peter Laca, Milan Schavel, Daniela Giertliova, Daria Kimuli, Peter Vasko, Ivan Duris, Igor Kmit, Katrina Mulama, Eva Grey

St. Philippe Rescue Center in an Area of high Prevalence of HIV Infection in Kisumu and Street Work for Street Boys in Nairobi

Ven Saosetha, Martina Utesena, Silvia Seckova, Zuzana Kubalikova, Juraj Benca, Veronika Sladeckova, Lesley Bucko, Andrea Shahum, Keo Vichet, Robert VIcek, Michael Olah, Leanghoin Hoin

Educational Social and Health Joint Bicoloral World \& SEU Program for HIV Positive Cambodian Children - Research Note

Barbara Silharova, Marian Holubcik, Vladimir Krcmery, Jose Suvada COVID-19 Pandemics in Uganda led to Cessation of the Comprehensive HIV Program in Rural Areas of North Lake Victoria Region. 
Maria Jackulikova, Maria Tothova, Jan Bydzovsky, Michal Olah, Maria Bielova, Igor Kmit, Peter Mlynarcik, Robert Vlcek, Vladimir Krcmery, Lisa Nguyen

Comparison of the Spectrum of Outpatient visits before and after

Fire in the Moria Camp after Arrival of Covid-19 Positive Refugees

Nasa Khan, Waseem Khan, Arab Naz, Aneela Sultana, Asmat Pasha

Understanding Pakhtun Woman's Vulnerability in Negotiation

with their Husbands for HIVIAIDS Screening

Daria Kimuli, Marian Barkovjak, Daniela Barkasi, Veronika Sladeckova, Ladislav Roman, Libusa Radkova, Vladimir Krcmery, Monika Palockova, Victor Namulanda

One Month or Real Life in a Single Clinic near the Slum Area in Mukuru

Urban setting in the Time after COVID-19 Epidemic in Kenya

Zuzana Kralova, Denisa Jakubcova, Victor Otieno Okech, Adriana Ondrusova

An Analysis of Anthropometric Measurements of Children Enrolled in

Programs for Managing Acute Malnutrition, in Kwale County, Kenya

Gaston Ngamygamie, Eva Smrekova, Vladimir Krcmery, Eva Horvathova,

Yoanna Trilisinskaya, Katrina Mulama

Highlands Malaria is Common but HIV very rare in Rural Areas of

Burundi 2,000 Meters above Sea Level (Short communication).

Adriana Liptakova, Martina Dubinova, Marek Straka, Jan Predny, Andrea Longauerova, Adriana Krajcikova, Alena Koscalova, Katarina VIckova, Martin Novotny, Pavol Jarcuska Application of Point-of-Care Testing (POCT) in Diagnostics of Influenza during COVID-19 Pandemic in elderly Hospitalized People (Short Communication)

Bozena Markovic Baluchova

Alleviation of Refugee Crisis in Lebanon through Humanitarian Aid Projects of Slovak Development Organizations in the Era of Covid-19 Pandemic

Jaroslava Pavelkova

Financial Literacy as one of the Professional Competencies of

Social Workers to Prevent or Solve Socio-economic Problems. 


\section{Editorial}

\section{Reducing COVID-19 Infection Exposures: Autonomy versus Non-Malificence}

Professor Costello has been a member of the University of Scranton faculty for 47 years. $\mathrm{He}$ is a retired health system executive and currently serves as Assistant Program Director for the University's Online MHA degree program.

CSWHI 2021; 12(1): 6 - 8; DOI: 10.22359/cswhi_12_1_15 C C Clinical Social Work and Health Intervention

\section{Abstract:}

\section{Introduction}

The COVID-19 pandemic has impacted 190 countries and territories, representing every region on Earth (Time.com). Some public health experts have opined that the world is beginning to experience a ,second wave" of infections after rampant spread began in the Spring of 2020.

Nations are growing concerned that increasing numbers of infections might jeopardize a country's ability to care for infected patients requiring hospitalizations, and potentially the use of ventilators which remain in short supply in some regions. Undoubtedly, increased testing for the virus has led to more people being identified as infectious, a prerequisite for specifying the incidence of infection.

Beginning in late October, Slovakia began an effort in the northern part of the country to test every adult under age 65 over a two-week period (Wall Street Journal, page A7). The plan was to test the target population twice by the end of the first week of November with the assistance of military personnel. Residents of the northern part of the country were to be prohibited from leaving their homes ,for almost any reason (ibid)“.

\section{Mitigation}

As the COVID-19 pandemic engulfed much of the world, public health officials began to publish advice as to how the public could best deal with the virus. Although the advice was sometimes contradictory and needed to be revised, certain recommendations remained fairly consistent. The World Health Organization (2020) stated:

- Maintain at least a 1-metre distance between yourself and others to reduce your risk of infection when they cough, sneeze or speak. Maintain an even greater distance between yourself and others when indoors. The further away, the better.

- Make wearing a mask a normal part of being around other people.

Somewhat inevitably, the public health guidance began to conflict with popular sentiment to reopen national economies, some of which were subjected to governmental restrictions in Spring 2020. Businesses feared financial ruin and millions of workers feared loss of income from governmental actions intended to ,flatten the curve“ of increasing infections. 
With the gradual resumption of certain activities, many began to question the need for wearing masks and engaging in social distancing. Younger people resumed socializing in bars and larger parties and infection rates began to increase in the summer months. After declining somewhat, in late summer the onset of autumn weather and a corresponding increase in indoor activity lead to an increase in infections, hospitalization and deaths in the northern hemisphere. In early September, the Institute for Health Metrics and Evaluation at the University of Washington Medical School in the US wrote ,nearly 700,000 lives worldwide could be saved between now and January 1 (2021) through proven measures such as mask-wearing and social distancing“" (IHME, September 3, 2020).

With the seeming relaxation of personal protective measures over time, combined with the scientific recommendations for curtailing the spread of the virus, the question arises why are some people ignoring the scientific advice from public health experts?

Many and varied explanations have been advanced as reasons for non-adherence to the mitigation advice. In October 2020, the incumbent President of the United States opined that national populations were suffering from ,pandemic fatigue" and were tiring of following public health recommendations for dealing with the virus. Other commentors suggested that personal and institutional economic pressures were leading some people to push for a return to a sense of normality which meant a relaxation of personal mitigation efforts.

An early theme advanced by some was that adherence to mask wearing and social distancing routines amounted to an assault on civil liberties and rights of privacy. Many who advocated these positions attempted to claim that requiring the wearing of masks and the maintaining of social distancing, as advocated by public health officials, constituted an improper intrusion of governmental authority, in some instances even involving constitutional protections.

Personal resistance to expert public health guidance suggests an over-reliance on the ethical principle of autonomy, at the expense of the principle of non-maleficence. Sometimes cited as the first principle of medical ethics, adherents to au- tonomy would argue that individuals have the ability and authority to determine whether or not they will comply with specific governmental regulation and public health guidance. Such adherence to autonomy becomes more problematic when one considers that the personal mitigation measures are designed to keep the individual from infecting other persons with whom they come in contact and are necessarily intended to protect the individual using the protective measures.

Costello (2019) wrote that „,most commentators would recognize some limitations to individual autonomy“ he cited Munson and Lague (2017) who wrote of the harm principle which may restrict the freedom of people to act if the restriction is necessary to prevent harm to others.'

Non-maleficence would seem to limit individuals who would take it upon themselves to act in ways that might harm other persons. Personal mitigation efforts including mask wearing and social distancing would demonstrate non-malificence in the effort to protect others from infection during this pandemic.

\section{Conclusion}

The COVID-19 pandemic appears to have upended much of everyday life as individuals work from home rather than in more traditional settings, students at all levels adapt to virtual technologies to avoid congretating in traditional learning sites, and businesses suffer from reduced patronage as customers seek to avoid some forms of these interactions.

Public health experts continue to advise the public to engage in rudimentary infection control measures including hand sanitation, mask wearing and social distancing to slow the speed of the virus. Unfortunately, many choose to ignore the guidance as too restrictive and a violation of their perceived autonomous rights to ignore public health experts.

The ethical principle of non-maleficence argues that all persons have an obligation not to engage in behaviors likely to cause harm to others. Hand sanitizing, mask wearing and social distancing are protective measures intended to keep those who engage in them from passing potential viral infection to others whom they come in con- 
tact with. The primary intention is not to keep the adherent from becoming infected. As such, arguments for avoiding personal protection measures must be balanced against an obligation not to infect other people.

Michael M. Costello, JD., MA Department of Health Administration and

Human Resources University of Scranton, PA, USA

\section{References}

1. WORLD HEALTH ORGANIZATION (2020) Coronavirus disease (COVID-19) advice for the public. www.who-int. Retrieved October 18, 2020.

2. COSTELLO M (2019) Medical AssistanceIn-Dying: The Conflict Between the Principles of Autonomy and Non-Maleficance and the Need For Dialogue. In Acta Missiologica, 13(2) 2019.

3. INSTITUTE FOR HEALTH METRICS AND EVALUATION (2020) First COVID 19 Global Forecast: IHME Projects ThreeQuarters of a Million Lives Could Be Saved by January 1. www.healthdata.org Retrieved October 17, 2020.

4. HINSHAW D (2020) All Adults Will Be Tested for COVID-19. In Wall Street Journal. October 24-25, 2020. Page A7.

5. MUNSON R, LAGUE I (2017) Intervention and Reflection: Basic Issues in Bioethics. Boston: Cengage Learning, 2017.

6. TIME.COM (2020) Where COVID-19 is currently spreading around the world. Retrieved October 18, 2020. 


\title{
The Emphasis on the Relevant Needs of the Parents of Extremely Premature Infants with Special Regard to the Impact of COVID-19
}

\author{
J. Masan (Jan Masan)1, K. Kolejak (Kamil Kolejak)²,
}

M. Hamarova (Mariana Hamarova) $)^{3}$

${ }^{1}$ University of Thessaly, Greece.

${ }^{1}$ University of Ss. Cyril \& Methodius in Trnava, Slovakia.

${ }^{2}$ Constantine the Philosopher University in Nitra, Slovakia.

${ }^{3}$ St. Elizabeth University of Health and Social Sciences, Bratislava, Slovakia.

\section{E-mail address:}

masanjan@gmail.com

\section{Reprint address:}

Jan Masan

Nálepkova 1

92101 Piestany

Slovakia

Source: Clinical Social Work and Health Intervention

Pages: $9-14$

Volume: 12

Issue: 1

\section{Reviewers:}

Andrea Shahum

University of North Carolina at Chapel Hill School of Medicine, USA

Pawel S. Czarnecki,

Rector of the Warsaw Management University, Poland

\section{Keywords:}

Extremely premature infant. Stress. Depression. Post-traumatic stress disorder. Parental needs. Social support. Stress management. Impact of COVID-19.

\section{Publisher:}

International Society of Applied Preventive Medicine i-gap

CSWHI 2021; 12(1): 9 - 14; DOI: 10.22359/cswhi_12_1_01 (C) Clinical Social Work and Health Intervention

\section{Abstract:}

This article draws from the results of a survey that was aimed at giving an overview and exploring in detail what needs the parents of extremely premature infants have and what options of social support they are provided with, especially during the period of the spread and subsequent impact of the COVID-19 pandemic. The research took place from the beginning of February 2020 until the beginning of September 2020. In the 
survey, 30 families participated from various countries, including Italy, Spain, the United States, Great Britain, Poland, Romania, and Ukraine. The results of this survey can be applied to produce analyses that will serve as the basis for future relevant and innovative research on the impact of COVID-19 on the global population.

\section{Introduction}

Physicians and medical staff currently succeed in saving extremely premature infants with an increasingly lower gestational age and birth weight, often under the established rate of survival. It is the group of newborns that is considered to be at the highest risk with respect to survival, possible complications, and the uncertainty of any prognoses. However, more and more parents owe their child's life and health to progress in neonatology. The expectations of parents, gynecologists, neonatologists and other specialists in this field may exceed the limits of what can be achieved in rescuing these children (5). Even in the medical specialties that progress rapidly they aren't always able to sustain health and life of all children (5). Therefore, the extremely premature infants require long-term special care and enormous patience not only on the part of health workers but, especially, parents. The parents, particularly the mother, are confronted with an unexpected situation for which they have had neither opportunity nor time to prepare. The effort aimed at saving the infant while separating the newborn from the mother immediately following delivery also represents the starting point of a long-term stressful process that involves both parents. During this process, they are forced to adapt to an abnormal and unforeseen situation, while facing the fear for the life of the infant, his or her health, future, and many other related negative sentiments. The article draws from the results of a survey that sought to provide an overview and explore in detail what needs the parents of extremely premature infants have and what options of social support they are provided with especially during the period of the spread and subsequent impact of the COVID-19 pandemic.

\section{Methods and findings}

The research took place from the beginning of February 2020 until the beginning of September 2020 . In the survey, 30 families participated from various countries, including Italy, Spain, the United States, Great Britain, Poland, Romania, and Ukraine. The families were approached through different non-governmental organizations and international interest groups involved in helping the parents of children with disabilities. Many of these infants were born extremely premature. Contacting the parents through such organizations provided necessary credibility as the parents had an opportunity to make sure that the authors of the article had many years of experience in this field. The survey was conducted by way of qualitative research methods, the main tool being an in-depth online interview with each family separately. The respondents were the parents of extremely premature infants aged 20-44. Before the survey started, they had agreed to the implementation of focus groups. The focus groups highlighted several crucial areas that ought to be prioritized when providing the parents with support, especially during the period of the spread and subsequent impact of the COVID19 pandemic. To a certain degree, the limiting factors of the research include its relatively short duration and the fact that the follow-up part of the survey is still under way; therefore, the results cannot be applied to the global population (yet).

The focus groups have shown that the fact that their baby was born as extremely premature lead the parents to ask themselves a series of questions that are very difficult to answer: Why our baby? What is the reason? What will the future development of our baby be? How is it going to affect our family? It is particularly the ,Why?“ question that is not actually a question but rather an expression of pain, fear, acrimony, anger, despair or hopelessness. In this situation, both parents need such a form of social support that would not only help them cope with the demanding new circumstances but also foster their selfesteem and self-appraisal and improve their skills to face the problem and find possible solutions to the new situation. Furthermore, the parents need significant support in their attempt to estab- 
lish a relationship with their baby. When coming to terms with a premature birth and its potential negative effects for the infant, the decisive role is played by the closest surroundings of the parents, their closest relatives and friends, and the medical staff with whom the parents remain in everyday contact on a long-term basis. However, the parents frequently have negative experience that even people in their surroundings and health workers do not know how to communicate with them, nor how to alleviate the situation for them. In addition, they were not provided efficient assistance or support in overcoming the anxiety and fear of the spread and subsequent impact of the Coronavirus pandemic. In this regard, they often expressed concern about the COVID-19 pandemic and its impact on the health of their child as well as on the future economic and social life of their family.

With respect to the focus group results, research was concentrated on following areas:

- in case of an extremely premature infant the parents need - from the perspective of the content of social support - emotional support during the entire hospitalization of the infant and the subsequent home care. This emotional support should seek to provide the parents with positive emotions by, for example, trying to be understanding; supplying hope, appeasement, affection, emotional proximity, empathy, kindness, and consolation; expressing interest in the parents' situation; building trust; and, fostering empathic listening thanks to which the parents may acquire a sense of security and acceptance and start gradually gaining confidence. The emotional support also includes the presence of the relatives and psychological or psychotherapeutic assistance for the parents, especially the mothers, during the hospitalization period and the subsequent home care. In addition to the emotional support the parents also need evaluation support that finds its expression in esteem, respect, appreciation, and the way people behave toward them. Such an attitude helps the parents be assured of their value and foster their self-esteem and effort to solve the situation independently. Thus, it becomes a positive source of their self-appraisal. Further, the parents of extremely premature infants need social support that provides guidance, social support that provides feedback, and individual social support. In connection with the altered types of social support and the provision of assistance to parents of extremely premature infants, there is also an ,urgent need to find a correct perspective on life as a whole again" (4). It is therefore necessary that the provision of social support begins with active listening. However, it is not only about what the parents say but also about understanding and comprehending what they seek to communicate (2);

- with respect to child care, the parents need instrumental social support, including household assistance, daily childcare assistance, and the provision of material things. Another necessity for the parents is informational social support that aims at helping them to get acquainted with further prognoses, the information concerning the condition and possible future development of their child, contact details for additional experts, and the particularities of childcare;

- the parents need to be continuously assured by people in their surroundings and medical staff that they can handle the emerged situation. Further, they need to share their concerns and experiences with other parents of extremely premature infants, often establishing and maintaining contacts and even friendships with them also at the international level through, for example, various international organizations. It is helpful when they see other extremely premature infants grow and flourish and when they feel they can ask about relevant problems that are of interest to them;

- the parents of extremely premature infants often face the downplaying, or else dramatizing, of their situation on the part of their family, surroundings or even health workers. On the contrary, for parents of extremely premature infants it is necessary to experience a strengthening approach: the so-called volitional positive attitude that encompasses acceptance and willingness to maintain contacts, and an intellectual positive attitude based on recognition and respect for them as parents (6). However, based on the experience of parents, they rather encounter unwillingness to perceive their situation more tactfully and with a more human approach, and a negative evaluation of, for example, their characteristics as parents (6). Accord- 
ing to the parents, they were shocked by the insensitive attitude of physicians and medical staff during communication or in the situations when they felt the need to see their child. Similarly, they are often subject to unpleasant questions from the medical staff or family;

- during the period when the fear of the COVID19 pandemic peaked the parents were not provided by the physicians and medical staff with efficient support that would have helped them manage their anxiety. Even today, the parents remain very concerned that they never received answers to some questions that were relevant for them. According to the parents, it was precisely the answers to these queries that would have helped them acquire a sense of perspective. In this respect, the survey focused on practicing mindful behavior with the parents of extremely premature infants as one of the most efficient psychological tools of managing the current impact of COVID-19. Developing a mindful approach involves therapeutic methods based on the practice of mindfulness (1). Within these methods, ,participants explicitly learn how to develop a mindful approach to their problems and how to use mindfulness in their everyday lives“ (7). Their attention focuses ,on the present moment, looking around and noticing what we normally cannot see. It teaches us to focus on colors, noises, smells, even the ones we have not perceived before. The main point is not to judge, evaluate or expect anything" (7).

When practicing mindful behavior, the parents were asked to fully concentrate on the present moment or the concrete activity they were doing, or about to do, at the moment. This activity must not be related to their child. The task of the parents was to be aware of the present moment and the performed activity without being distracted by unrelated thoughts, images or emotions. The goal was to concentrate the psychological flexibility of the parents and their openness toward various aspects of this activity by focusing their full attention on the activity itself, rather than its results. In the course of mindful behavior, the attention of the parents is shifted, without being forced, to the individual aspects of a particular activity that are then explored from various perspectives. One of the common examples is manual dish-washing when one practices mindful behavior through being aware of the warm sensation in one's hands, the shine of clean dishes or body movements. After this regular-session training was finished, each parental couple had their separate evaluation session. The training of mindful behavior that lasted several months and was modified to meet the needs of the parents of extremely premature infants has proven to be effective in attenuating the ruminations about the condition of their child or the anxiety related to the impact of COVID-19.

Each family that participated in the research experienced the birth of an extremely premature infant differently. Also, they come to terms with the new situation differently, based on the living, social, and economic conditions in the country they live in. The stance of the families on their situation can be divided into several categories: - the families that accept the situation as it is, being aware that they have to come to terms with it in a certain way. These families have opted for a strategy of acceptance. They strive to accommodate to the situation as much as possible, operating within their resources;

- the families that perceive the situation optimistically. The survey results have shown that the families with this attitude predominantly seek to minimize the image of the difficult situation. In the case of these families one can observe a defense mechanism that lapses into an escape strategy. In this regard, too, the training of mindful behavior was very efficient for the families. It helped the families to see how they can ,disregard“" the challenging situation without trying to escape;

- the families that have a categorically negative attitude to the emerged situation. These families are convinced that the scenario will be the worst possible, including the severe disabilities of the child. Being under permanent pressure, everyday situations are very stressful for them. Members of these families are often liable to panic and angst. They regularly tend the child with exaggerated and irrelevant protection that results in ever greater tension and stress. The practice of mindful behavior enables them to better realize the ,here and now.“ It instructs them to eliminate the ruminations about various concerns. This practice can be particularly 
efficient if the families pursue it through various meditation techniques, focused on, for instance, breathing, body, motion, the uncritical observation of thoughts and images, that significantly contribute to reducing tension, anxiety, and stress.

\section{Discussion}

The in-depth online interview with the families was challenging for many parents as it recalled the painful times when they had undergone the excessive stress due to the threat to the life of their child. Many parents were moved by intense emotions during the conversation. With regard to the fact that the survey was conducted during the spread of the COVID-19 pandemic, this issue echoed with the parents immensely, exacerbating their stress and angst. As a response to this situation, numerous parents indicated depression or post-traumatic stress disorder (PTSD). This was one of the reasons why the research also included several months of modified mindful behavior training intended for the needs of the parents of extremely premature infants. It helped them develop a decentered distance from their own negative thoughts and emotions by concentrating on a specific activity.

Furthermore, the research highlighted the importance that those around the parents of extremely premature infants often do not understand what the parents must go through, nor can they fathom what the care of such an infant involves and what his or her parents need to face.

The theme of extremely premature infant care and of the efficient support for their parents is becoming ever more relevant in this period, affected by different COVID-19-related measures. At the same time, however, one needs to keep in mind that such care and support must also take into consideration the idea of upholding the dignity of the parents of these children who have suddenly and unexpectedly happened to be in a difficult situation and are in need of social support in all possible areas; what efficient strategies and methods can help these parents mobilize their internal resources; how to let them know that both their child and themselves matter and are a visible and important part of society or the community - that they are valuable and that somebody genuinely and sincerely cares for them...

\section{Conclusion}

Today, a system of social relationships with people participating in a communicational network is becoming ever more relevant. These relationships are perceived as subjectively important for maintaining one's own identity and mental balance (3). One finds security in positive social relationships that help one overcome challenging life situations and represent a common source to enable experiencing the meaningfulness of life. The phenomenon of social support thus represents a social pool from which one can benefit in case of need; it influences the way one copes with difficult, challenging, and stressful events and alleviates their consequences. It is also related to the quality of life and an experienced happy life in the case of the families of extremely premature infants.

The results of this survey can be applied to produce analyses that will serve as the basis for future relevant and innovative research on the impact of COVID-19 for the global population.

\section{References}

1. KABAT-ZINN J (1990) Full catastrophe living: Using the wisdom of your body and mind to face stress, pain, and illness. New York: Delta Trade Paperback/Bantam Dell.

2. KRIVOHLAVY J (2009) Nurse and stress. Praha: Grada Publishing.

3. Levicka, J (2004) Basic of social work. Trnava: FZaSP TU.

4. SMIDOVA M, TREBSKI K, NEMCIKOVA M (2019) Quality in long-term care: Central European people-centered assessment principles and their calls for an efficient interdisciplinary dialogue. In Acta Missiologica, 201913 (2) p. 209. ISSN: 1337-7515 (Print) ISSN: 2453-7160 (On-line) https://www.actamissiologica.com/.

5. PERI H A, SUBRAMANIAN S, SLADECKOVA V, BYDZOVSKY J, DURCOVA B, KUBALIKOVAZ, OLAH M, MATULNIKOVA L, DOKTOROV A, BERESOVA A, KUBIK F, FULA M, OTRUBOVA J, KALATOVA D, KUKUCKOVA E, JURINOVA S, BENCA J, SHAHUM A, HOY LEANG HOINAND CHENG HOIN, SETA S/ Early detection of adverse therapy reaction in orphan children with AIDS (short communication) 
In: Acta Missiologica. - ISSN 1337-7515. Vol. 13, no. 2 (2019) p. 184-187.

6. TRIZULIAKOVA J, KRCMERYOVA L, MOJZESOVA M (2020) Prenatal Palliative Care and Perinatal Hospice - New Challenges in Caring for the Precious Gift of Life in its Fragility. In Clinical Social Work and Health Intervention, 202011 (1) p. 49. ISSN: 20769741/online ISSN: 2222-386x/Print DOI 10.22359/cswhi_11_1.

7. ZAMKOWSKA A, OLZEWSKI M (2020): Families with a Disabled Child's Perception of Societal Attitudes Towards Them. In Clinical Social Work and Health Intervention, 202011 (1) p. 57. ISSN: 2076-9741/online ISSN: 2222-386x/Print DOI 10.22359/cswhi_11_1.

8. VARGHESE J et al (2020): Certain negative consequences related to the coronavirus pandemic and relevant possible solutions. In Acta Missiologica, 201913 (2) p. 85. ISSN: 13377515 (Print) ISSN: 2453-7160 (On-line) https://www.actamissiologica.com. 


\section{HIV Mobile Clinic as a Part of the Comprehensive Social and Public Health Program in the Malindi Coastal Area}

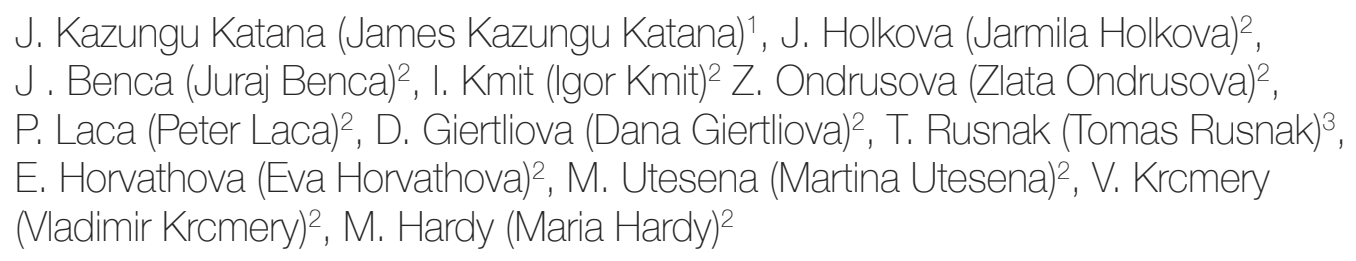

${ }^{1}$ Ushirikiano Centre SEU Tropical Program Malindi, Kenya.

${ }^{2}$ Slovak Tropical Institute Dept. Tropical Disease SEU and

Slovak Medical University school of Medicine and School of Public Health, Slovakia.

${ }^{3}$ St. Philip Neri rescue center Kisumu, Kenya.

\section{E-mail address:}

jimmy.katana.big1@gmail.com

\section{Reprint address:}

James Kazungu Katana

Ushirikiano Centre, St. Mary's Catholic Mission

Msabaha, P.O. Box 256,

80200 Malindi

Kenya

Source: Clinical Social Work and Health Intervention

Volume: 12

Issue: 1

Pages: $15-16$

Cited references: 3

\section{Reviewers:}

Daria Kimuli

Catholic University of Eastern Africa, Nairobi, Kenya

Lesley Bucko

Phnom Phen, Cambodia

\section{Keywords:}

HIV. Screening.

\section{Publisher:}

International Society of Applied Preventive Medicine i-gap

CSWHI 2021; 12(1): 15 - 16; DOI: 10.22359/cswhi_12_1_02 (C) Clinical Social Work and Health Intervention

\section{Abstract:}

The Unshurikian Center is one of the classical examples of a social and health related joint venture suitable for sub-Saharan Africa focused on social work with poor families; support of children from low income families to visit school; outpatient services for basic diseases in the coastal area; and HIV Outreach Program running for 12 years. 


\section{Introduction}

The coastal area of Kenya is full of social and health care contrasts such as modern first class hotels for EU tourists neighboring with poor rural satellites and villages. The aim of this short communication is to underline the screening for HIV in this area famous for sexually transmitted diseases due to tourism and extreme poverty helping many families to survive despite the huge risk acquiring STD including HIV and hepatitis C within last 20 years which may be a real threat not only for dissemination of HIV but also other related STD diseases having consequences for families and demographic adverse outcomes.

\section{Methods and setting}

The Malindi area has about 100,000 inhabitants and about 10,000 tourists mainly from Italy and other EU countries close to another resort area of Mombasa and historical Lamu. Mombasa is visited weekly with about 20.000 tourists for sports, sea activities and history. But Malindi is famous by sex tourism and first class beach hotels. However, neighborhoods of Malindi include areas affected with extreme poverty. Therefore, a part of Ushurikiano comprehensive educational school and anti-malnutrition program, also conduct screening for HIV by active surveillance performed twice a month by our staff.

\section{Results and discussion}

The number of clients for active social work reaches $80-100$ weekly in adults and up to 200 children, the commonest social pathology and aims of social work include items in Table 1:

\section{Table I.}

Reasons for social work and commonest social pathology Ushurikiano Malindi

1. poverty and lack of proper nutrition 80-100 families, up to $100 \%$ of visits

2. need for educational support 135 children

3. substance and alcohol abuse $20 \%$

4. domestic violence $21 \%$

5. CAN $13 \%$

6. prostitution $7 \%$

7. crime $3.5 \%$

8. HIV prevalence $5-10 \%$

HIV mobile testing with the rapid test is performed once monthly for $50-60 \%$, and this num- ber as well as the proportion of positives is relatively stable and decreased from 10-15\% 20 years ago to $5-10 \%$ nowadays, also due to the decreasing number of sex tourists after kidnappings in Lamu and terrorist attacks in Mombasan hotels with tourists from Israel 10 years ago.

\section{Conclusions}

Active surveillance for HIV and TB is important in all touristic centers in coastal Eastern Africa, including Muslim areas of Pemba Zanzibar and Tanzania, since most of the STD,s are imported. Prostitution has economic rates and economic consequences and is also related to lower education. Therefore, major strategic plans for this area is

a. to support to bring the children from household and poverty to school and support the education

b. ensure improved nutrition supporting small business in families and assist single mothers

c. continue with 10 years history of active surveillance of HIV at least on a monthly basis which is a part of HIV may diagnose also related STD and TB

\section{References}

1. WHO ANNUAL REPORT - SUB-SAHARAN AFRICA (2017) World health Organisation Genève, 2017. 265 pp.

2. PLACKOVA A, ONDREICKOVA A (2019) Pain - importance for rehabilitation, Rehabilitation, Vol 56, No 4, 2019, ISSN 0375-0922, s.21-40.

3. UNITED NATIONS AIDS PROGRAM (2015) UN New York, UN publishing House, 2015. 145 pp. 


\title{
Covid-19 has only Temporarily Interrupted Social and Health Services in rural Albania in $\mathbf{2 0 2 0}$
}

\author{
M. Palockova (Monika Palockova)1', S. Chovancova (Stanislava Chovancova)², \\ D. Sugarova (Daniela Sugarova)², E. Zdilova (Eva Zdilova) ${ }^{2}$, F. Sasvary (Ferdinand \\ Sasvary)2, M. Sasvary (Maria Sasvary)2, D. Barkasi (Daniela Barkasi) $)^{3}$, M. Gulasova \\ (Monika Gulasova) $^{3}$, I. Kmit (lgor Kmit)3 ${ }^{3}$, M. Olah (Michal Olah)3) R. Hochman (Rastislav \\ Hochman) ${ }^{3}$, E. Haluskova (Eva Haluskova) ${ }^{3}$, M. Partelova (Martina Partelova)², \\ E. Trichard (Emanuel Trichard) $)^{4}$
}

${ }^{1}$ St. Francis School Sisters, Fier, Republic of Albania.

${ }^{2}$ St. Elizabeth University Migrant \& Refugee Program, PhD program Balkan Branch Fier Albania.

${ }^{3}$ Dept. of Tropical Diseases, Slovak Medical University Bratislava, Slovakia.

${ }^{4}$ Integrated Group of Applied Public Health IGAP Vienna, Austria.

${ }^{5}$ PRIGO University, V. Nezvala 801/1, 73601 Havirov, Czech Republic.

\section{E-mail address:}

palockova@yahoo.fr

\section{Reprint address:}

Monika Palockova

St. Francis School Sisters

Fier

Republic of Albania

Source: Clinical Social Work and Health Intervention

Pages: $17-19$

Volume: 12

Issue: 1

\section{Reviewers:}

Pedro Allegria

Mozambique

Victor Namulanda

Nairobi

\section{Keywords:}

Outpatient. Health Services. Covid-19.

\section{Publisher:}

International Society of Applied Preventive Medicine i-gap

CSWHI 2021; 12(1): 17 - 19; DOI: 10.22359/cswhi_12_1_03 CC Clinical Social Work and Health Intervention

\section{Abstract:}

During the first and second wave of Covid-19 pandemics, Balkan countries were among the least affected areas of Europe, especially those having islands as naturally protected quarantine environment (Greece, Croatia, Cyprus, Malta), as well as countries with less tourism in Spring such as Montene- 
gro, Albania, and Bulgaria. Therefore, the health care system was not overwhelmed by Covid-19 infected patients and was able to continue on normal outpatient and inpatient bases. This pilot population-based study in rural Albania shows only a low and temporary break of health and social services for just 1 month during the first wave, in April 2020.

\section{Introduction}

Primary mortality of Covid-19 varies between $0.5 \%$ (SK, MT, CYP) to $13.5 \%$ (FR), however, this is only a death rate due to virus related lung disease. Secondary mortality involves the cessation or total absence of health services for diagnosis other than Covid-19, as it was seen in Northern Italy in March and April 2020, and tertiary mortality is due to the collapse of the economy and therefore insufficient funding of health national programs such as those aimed at cardiovascular diseases or cancer.

This population-based survey presents an example of one of less affected Mediterranean Balkan countries during the first wave, where primary mortality was minimal, and secondary only indirect since the interruption of health services was experienced for one month only.

\section{Setting Methods}

The City of Fier is located in southern central Albania in an area with lower income, and limited access to hospital healthcare and previously no free of charge outpatient service. The Franciscan School Sisters from Prievoz have founded the community center also providing health and social services. In addition, they have started an outreach program aimed at households in remote villages of low economic status in order to help them with access to health care, irrespective of their socio-economic status. The project contained 4 health care workers -1 doctor and 3 nurses, and 1 social worker (French or Slovak) from January to December 2020. We have compared the number of visits during the lockdown in first wave of Covid-19 in April 2020 to other months after the quarantine measures were stopped in May 2020.

\section{Results and discussion}

Patient's flow decreased to zero in April 2020 due to the lockdown, dropping from the average of more than 110 patients per month that had vis- ited the facility in period from January to March 2020. However, it started to increase from May till September 2020. Altogether, 331 outpatient visits were recorded in 2 months, plus 121 outreaches to the rural villages starting in June.

In contrast to OPD spectrum in tropical areas, e.g. Sub-Saharan Africa, where communicable diseases of 3 major killers (HIV, TB, and malaria) are prevalent (2). In Albania non-communicable diseases are still prevalent in the adult population, including hypertension, diabetes mellitus, bronchial asthma, coronary heart disease, and in children upper respiratory tract infections followed by injuries, burns, wounds and trauma.

No confirmed cases of TB, HIV and vivax malaria were documented even during summer and touristic season. Endemic zoonoses (listeriosis, Q-fever, leishmaniasis, echinococcosis) were extremely rare. Substance abuse, including alcohol overuse, was much lower than expected.

\section{Conclusion}

Despite of Mediterranean food habits and continuous physical activity during its agricultural lifestyle, the spectrum of the commonest diseases, including civilization diseases, resulting in outpatient visits in rural southern Albania is much closer to central eastern Europe than to the sub-tropical Mediterranean Region of WHO. As the access to the health care in rural villages of Albania is limited, the outreach strategy is performed every week, similarly to what is performed in other projects in countries with limited access to funding and medications.

Preventive strategies and health policy should be focused on cessation of smoking, regular blood pressure and blood glucose measurement in adults, and on asthma and prevention of injuries in children. Vaccination policy has been maintained during the last 70 years on an acceptable level, all children seen in OPD had the basic vaccination (DTPHiB, HB, Polio plus MMR plus TB) as a result of centralized public health care 
system and universal access to education and basic health care.

\section{References}

1. KIMULI D (2020) Social and Health Programs in Sub-Saharan Africa. Med Horizon 70.2020 .6 .

2. DANCAK P 2019 Dialogue and Solidarity as a Basis for Addressing the Current Migration Crisis. In: Acta Missiologica INo. 2|Vol. 13l2019| pp. 73-83. ISSN 1337-7515.

3. WHO ANNUAL Report (2015) section Mediterranean Region, European Region, World Health Organization, Geneva - pp155-204 


\section{St. Philippe Rescue Center in an Area of high Prevalence of HIV Infection in Kisumu and Street Work for Street Boys in Nairobi}

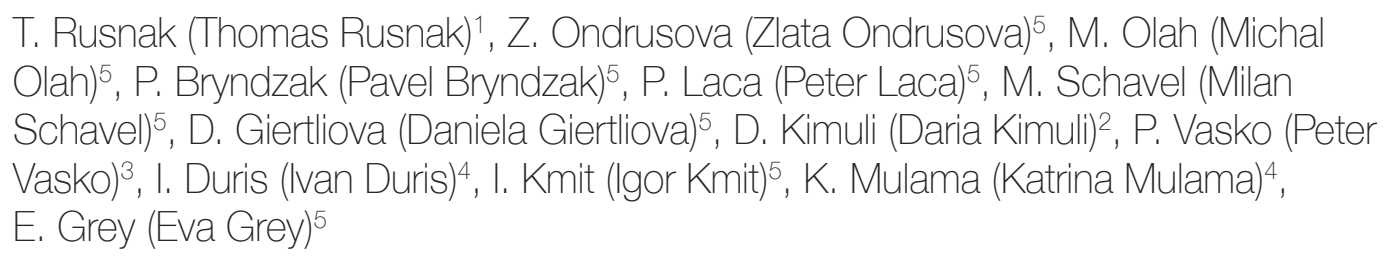

${ }^{1}$ St. Philippe Neri Rescue Centre SEU University Anti-malnutritional Program Kisumu, Kenya.

${ }^{2}$ St. Philippe Neri School Joshka, St. John Paul II School of Missiology SEU Bratislava in Joshka, Kenya.

${ }^{3}$ Oasis of peace love and mercy, Nairobi, Kenya.

${ }^{4}$ Dr.David Roden Tikit Mission health centre, West Pokot, Kenya.

${ }^{5}$ Dept. of Tropical Diseases, Slovak Medical University Bratislava, Slovakia.

\section{E-mail address:}

frolinek@gmail.com

\section{Reprint address:}

Tomas Rusnak

St. Philip Neri rescue center

P. O. Box 68

40100 Kisumu

Kenya

Source: Clinical Social Work and Health Intervention

Volume: 12

Issue: 1

Pages: $20-22$

Cited references: 2

\section{Reviewers:}

Vitalis Okoth

Hargeisa, Somalia

Johnson Mawole

Nyanza, Tanzania

\section{Keywords:}

Street boys. HIV.

\section{Publisher:}

International Society of Applied Preventive Medicine i-gap

CSWHI 2021; 12(1): 20 - 22; DOI: 10.22359/cswhi_12_1_04 CC Clinical Social Work and Health Intervention 


\section{Abstract:}

\section{Introduction}

Street boys in slums of large African Urban settings such as Kibera in Nairobi or Soweto in Johannesburg are probably the largest concentrations of youth associated social pathology worldwide. Here we present two examples of effective street work programs: one in Kisumu, focused on the strategy to bring the children from street to school and sports, in a large HIV prevalence City of Kisumu; and vice versa, an street work program focused on narcotic cessation as an exchange for food and potential sheltering in one of the largest slums in Africa in Kibera, Nairobi.

\section{Settings and Methods}

Kisumu is a town in the highest endemic area for HIV and malaria. Near Lake Victoria, in Western Kenya it has a population of up to 150,000 ; Nairobi has more than 10 million, with at least 6 large slum areas the largest in Kibera with about 950,000 people living in critical housing and poverty conditions. First setting in Kisumu is using full board shelter to attract street boys including sport and education. A second project is using food and potential upgrade to their community for those who voluntary accept the cessation of glue, gasoline or other inhalational substance use.

\section{Results and Discussion}

The spectrum of social pathology and three major killer diseases is in table 1. As in Kisumu, substance use is less frequent but HIV and Malaria common. In Nairobi crime and substance inhalational use is more common. Due to altitude, malaria is less frequent and Hiv under better control due to active screening by the government and NGOs.
Table 1: Spectrum of Social Pathology in two sites ofactive social intervention for street boys

\begin{tabular}{|lll|}
\hline Social pathology & Kisumu & $\begin{array}{l}\text { Nairobi } \\
\text {-Kibera }\end{array}$ \\
\hline Substance inhal.use & rare & frequent \\
\hline Illiteracy & common & less \\
\hline Malnutrition & less & common \\
\hline Crime & less & common \\
\hline HIV malaria & more & less \\
\hline Tuberculosis & less & more \\
\hline
\end{tabular}

The worst stages of substance inhalational abuse - so called gasoline and glue dementia may be seen in Nairobi slums, where the number of street boys may exceed 100,000 and therefore street work is more dangerous for social workers. Sports and education is offered to those willing to join the St. Philippe Neri Community in Kisumu.

\section{Conclusion}

Motivational street work with incentives such as food, shelter, day center created hygiene, sports, education is an important factor to improve the motivation of street boys for a better future. Very important. if not crucial. is also the pastoral work and offer of various religious services for this vulnerable group of population.

\section{References}

1. PROCHAZKOVA K., KOVAC R, OLAH M et al (2018) High threshold shelters in an urban large setting, Clinical Social Work Journal, 2018. 9. 44.

2. PERI H A, SUBRAMANIAN S, SLADECKOVA V, BYDZOVSKY J, DURCOVA B, 
KUBALIKOVA Z, OLAH M, MATULNIKOVA L, DOKTOROV A, BERESOVAA, KUBIK F, FULA M, OTRUBOVA J, KALATOVA D, KUKUCKOVA E, JURINOVA S, BENCA J, SHAHUM A, HOY LEANG HOINAND CHENG HOIN, SETA S/ Early detection of adverse therapy reaction in orphan children with AIDS (short communication) / In: Acta Missiologica. - ISSN 13377515. - Vol. 13, no. 2 (2019) p. 184-187. 


\section{Educational Social and Health Joint Bicoloral World \& SEU Program for HIV Positive Cambodian Children - Research Note}

V. Saosetha (Ven Saosetha)1', M. Utesena (Martina Utesena)², S. Seckova (Silvia Seckova)², Z. Kubalikova (Zuzana Kubalikova)², J. Benca (Juraj Benca)², V. Sladeckova (Veronika Sladeckova) ${ }^{3}$, L. Bucko (Lesley Bucko)², A. Shahum (Andrea Shahum) 5 , K. Vichet (Keo Vichet) $)^{4}$, R. Vlcek (Robert Vlcek)2, M. Olah (Michael Olah) ${ }^{3}$, L. Hoin (Leanghoin Hoin)

${ }^{1}$ Bicoloral World NGO Branch for Phnompenh Sihanoukville, Kingdom of Cambodia.

${ }^{2}$ St. John Paul School of Missiology St. Elizabeth SEU University Polianky, Slovakia.

${ }^{3}$ Dept. of Tropical Diseases, Slovak Tropical Inst. Slovak Med University Bratislava, Slovakia.

${ }^{4}$ House of Hope, House of Family, House of Smile, St Elizabeth University HIV , Program in Cambodia, Phnompenh, Kingdom of Cambodia.

${ }^{5}$ Stamford Health Tully Healt Center, USA.

${ }^{6}$ Cambodian Children's Fund Phnom Penh, Kingdom of Cambodia.

\section{E-mail address:}

sao.setha@gmail.com

\section{Reprint address:}

Ven Saosetha

House of Family

Phnom Penh

Cambodia

Source: Clinical Social Work and Health Intervention

Volume: 12

Issue: 1

Pages: $23-25$

Cited references: 5

\section{Reviewers:}

Selvaraj Subramanian

Kualalumpur

Mageswari Rajoo

Kualalumpur

\section{Keywords:}

Pediatric HIV. Education. Orphans.

\section{Publisher:}

International Society of Applied Preventive Medicine i-gap

CSWHI 2021; 12(1): 23 - 25; DOI: 10.22359/cswhi_12_1_05 (C) Clinical Social Work and Health Intervention

\section{Abstract:}

In areas of higher HIV prevalence in Southeastern Asia, joint programs focused not only on HIV screening and detection in street children, but also joint strategies such as to bring children 
from street to school as well as full-board shelters. These are important because only HIV chemotherapy is sufficient to prevent reinfection and achieve adherence to medications mainly in children and adolescents in remission. This research note presents a 20 years comprehensive program for 105 children, $80 \%$ HIV positive in Phnompenh and Sihanoukville Kingdom of Cambodia centers.

\section{Introduction}

Prevalence of HIV in children in Southeast Asia is decreasing due to investments for prevention, active screening, education and highly active anti-retroviral therapy being available since 2010 for all children in the Kingdom of Cambodia for free(1). When in 1999-2001 the occurrence of HIV in large urban settings was $1-3 \%$ in children and $2-5 \%$ in adults. Currently after initiation of HAART in 2010 the numbers are steadily decreasing. This is to present a comprehensive program including sheltering, education, anti-malnutrition and HIV testing programs at two orphanages in Phnompenh and Sihanoukville running for 20 years.

\section{Setting and Methods}

This is a descriptive research note showing the successful combination of three strategies-education plus social work (housing \& nutrition) plus HIV management in a two tailed cohort of 105 children: 45 and 35 still sheltered or in halfway houses (adolescents) and 25 already left and running their own businesses and families (married); 38 plus 28 children still on anti-retroviral therapy in complete and 2 in partial remission in two social health education combined shelters serving orphans with full board and free HAART donated by the government.

\section{Results}

In 20 years, of 105 children, only 4 died and 4 were lost in follow up; $93 \%$ retained in one of the projects either full board shelter or half way housing as the guided way to independence; 14 completed our study in University. Only 4 severe complications of HAART occurred in last 5 years and none of children died from adverse drug reaction; despite about $30 \%$ to $40 \%$ having received concomitant treatment for tuberculosis. The staff, including one foreign doctor or social worker and 8 plus 5 local staff supervise school attendance, cultural and sport activities; adherence to anti-retroviral therapy; acceptance of local housing rules including 3-5 times daily food including meat and fresh fruit daily to ensure proper nutrition as a part of comprehensive psychosocial nutritional and anti-retroviral complex therapy of both HIV and their orphan status.

\section{Conclusions}

Children with HIV and TB need comprehensive approaches including positive psychosocial stimulation, effective anti-retroviral therapy, food rich in vitamin elements as part of anti-infectious complex management; motivational education. This is one of the explanations, why children in our project and other projects in Southeast Asia including Vietnam, Cambodia, Thailand, etc. have better outcomes as similar children in SubSaharan Africa where malnutrition and lack of school and educational support may be responsible for worse outcomes for pediatric HIV.

\section{References}

1. WORLD HEALTH ORGANISATION ANNUAL REPORT (2018) South East \& Western Pacific Region. WHO Geneve (2018) p 355.

2. MASAN J, SRAMKA M, SABO A, KALATOVA D, ROTTERMUND J, RUZICKY E (2020) The covid-19 disease situation prior to October 2020 in selected countries: the potentially severe consequences of Covid-19 on the nervous system and several key solutions to Covid-19 in relation to digitization and artificial intelligence. In: Acta Misiologica / Bucko Ladislav. - ISBN 2453-7160. - Vol. 14, no. 2 p. 112-126.

3. PERI H A, SUBRAMANIAN S, SLADECKOVA V, BYDZOVSKY J, DURCOVA B, KUBALIKOVA Z, OLAH M, MATULNIKOVA L, DOKTOROV A, BERESOVA A, KUBIK F, FULA M, OTRUBOVA J, KALATOVA D, 
KUKUCKOVA E, JURINOVA S, BENCA J, SHAHUM A, HOY LEANG HOINAND CHENG HOIN, SETA S/ Early detection of adverse therapy reaction in orphan children with AIDS (short communication) / In: Acta Missiologica. - ISSN 1337-7515. - Vol. 13, no. 2 (2019) p. 184-187.

4. SECKOVA $S$ et al (2016) 15 years of Follow up in Cambodian children with HIV. Clinical Social Work. 5.2016.33

5. KOTLAROVAZ (2020) Sexual Risk Behavior

- Prostitution. In Health and Social Work.

p. 64-69. ISSN 1336-8326. 


\section{COVID-19 Pandemics in Uganda led to Cessation of the Comprehensive HIV Program in Rural Areas of North Lake Victoria Region}

\section{B. Silharova (Barbara Silharova)1, 2, M. Holubcik (Marian Holubcik)1, 2, V. Krcmery (Vladimir Krcmery)1,2, J. Suvada (Jose Suvada) 1, 2}

${ }^{1}$ St. John Paul II Clinic, Health Initiative Associates and St. Elizabeth

University Tropical, Slovakia.

${ }^{2}$ Slovak Medical University SZU, Tropical Diseases Program Buikwe, Uganda.

\section{E-mail address:}

barbora.silharova@gmail.com

\section{Reprint address:}

Barbora Silharova

Health Initiatives Association, Clinic Jan Pavol II. Buikwe

Uganda

Source: Clinical Social Work and Health Intervention

Pages: $26-27$
Volume: 12

Cited references: 2
Issue: 1

\section{Reviewers:}

Daria Kimuli

Catholic university of Eastern Africa, Nairobi, KE.

Jarmila Holkova

Malindi

\section{Keywords:}

Covid 19. HIV.

\section{Publisher:}

International Society of Applied Preventive Medicine i-gap

CSWHI 2021; 12(1): 26 - 27; DOI: 10.22359/cswhi_12_1_06 (C) Clinical Social Work and Health Intervention

\section{Abstract:}

15 years of sustainable activity in Buikwe and the rural area in Lugazi Province Republic of Uganda has led to a substantial decrease of HIV. However, this disease is still, together with malaria, the most important public health problem in the North Lake Victoria region. Unfortunately, arrival of Covid-19 led to a temporary decrease of outreach activity due to decreased mobility and restrictions. Therefore, the HIV epidemic may spread just due to the secondary effect of another epidemic diseases. 


\section{Introduction}

HIV Malaria and TB still are major killers among diseases in Sub-Saharan Africa. However, the arrival of Covid-19 may have an adverse effect on control of those three major public health problems due to funds consumed instead of e.g. HIV for Covid disease. In addition also non-communicable diseases such as hypertension, diabetes etc. are emerging events in rural Africa. 15 years of sustainable activity in Buik a rural area in Lugazi Province Republic of Uganda has led to a substantial decrease of HIV. However, this disease is still, together with malaria, the most important public health problem in North Lake Victoria region. Unfortunately, arrival of Covid19 led to temporary decrease of outreach activity due to decreased mobility and restrictions, therefore the HIV epidemic may spread just due to secondary effect of another epidemic diseases.

\section{Patients and Methods}

The capacity of the St. John Paul II Clinic of Health associates with an initiative HIA powered by the St. Elizabeth University Tropical Diseases Program serves two Outpatient Departments: with one for chronic diseases; one for incoming outpatients; both serving approximately 540 and 500 patients per month.

In addition, an anti-malnutrition program is active for 30 supports a month and TB therapy is included in comprehensive health services as well.

Four preventive programs in health care within the last year including spiritual assistance monthly is complemented by a social program for 579 households with 1,969 children.

Another 691 families received financial assistance or social support including of 625 those who received school support or educational support within the community.

\section{Results and discussion}

Spectrum of non-communicable and communicable diseases in Outpatient Departments serving approximately 500 patients monthly included the following diagnoses:

- sickle cell anemia $11 \%$

- hypertension plus diabetes about $4 \%$

- isolated diabetes $4 \%$

- isolated hypertension 5\%

- respiratory tract infections about $30 \%$
- malaria $10 \%$

- gastroenteritis $15 \%$

Twice monthly HIV outreaches have been performed for 10 years leading to a decrease of HIV prevalence and also TB sporadicity, however since the Covid-19 alert in Uganda, this service has to be stopped.

\section{Conclusions}

A disease pandemic may adversely affect other diseases crucial for public health status in Sub- Saharan Africa such as screening for malaria, TB and HIV. Because the Covid-19 prevalence in rural African areas is lower than in the USA and Europe, hopefully the screening programs will be reopened to continue the everlasting battle against HIV, TB and other tropical diseases.

\section{References}

1. MASAN J, SRAMKA M, SABO A, KALATOVA D, ROTTERMUND J, RUZICKY E (2020) The covid-19 disease situation prior to October 2020 in selected countries: the potentially severe consequences of Covid-19 on the nervous system and several key solutions to Covid-19 in relation to digitization and artificial intelligence. In: Acta Misiologica / Bucko Ladislav . - ISBN 2453-7160. - Vol. 14, no. 2 p. 112-126.

2. PERI H A, SUBRAMANIAN S, SLADECKOVA V, BYDZOVSKY J, DURCOVA B, KUBALIKOVA Z, OLAH M, MATULNIKOVA L, DOKTOROV A, BERESOVAA, KUBIK F, FULA M, OTRUBOVA J, KALATOVA D, KUKUCKOVA E, JURINOVA S, BENCA J, SHAHUM A, HOY LEANG HOINAND CHENG HOIN, SETA S/ Early detection of adverse therapy reaction in orphan children with AIDS (short communication) / In: Acta Missiologica. - ISSN 13377515. - Vol. 13, no. 2 (2019) p. 184-187. 


\title{
Comparison of the Spectrum of Outpatient visits before and after Fire in the Moria Camp after Arrival of Covid-19 Positive Refugees
}

\author{
M. Jackulikova (Maria Jackulikova) ${ }^{1}$, M. Tothova (Maria Tothova) ${ }^{3}$, J. Bydzovsky \\ (Jan Bydzovsky)3), M. Olah (Michal Olah) $)^{3}$, M. Bielova (Maria Bielova) $)^{3}$, I. Kmit

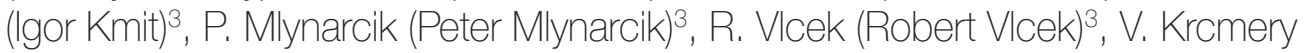 \\ (Nladimir Kromery)2, L. Nguyen (Lisa Nguyen) $)^{4}$
}

${ }^{1}$ SEU Refugee and Migrant Program UNHCR Camp Moria Lesbos, Greece.

${ }^{2}$ Slovak Medical University Bratislava Slovak Tropical Institute and Dept. of

Original Article Tropical Diseases SZU Bratislava, Slovakia.

${ }^{3}$ Refugee and Migrant Program St. John Paul II. School of Missiology and Dept. of Social Work Polianky, Slovakia.

${ }^{4}$ C.M.A Crisis Management Association, Greece.

\section{E-mail address:}

Maria.jackulikova@gmail.com

\section{Reprint address:}

Maria Jackulikova

C.M.A Crisis Management Association,

Mytilene, Lesbos

Greece

Source: Clinical Social Work and Health Intervention

Pages: $28-30$

Volume: 12

Issue: 1

\section{Reviewers:}

Vlastimil Kozon

AKH Vienna

Victor Namulanda PhD

MIC Nairobi

\section{Keywords:}

Refugees. Migrants. COVID-19.

\section{Publisher:}

International Society of Applied Preventive Medicine i-gap

CSWHI 2021; 12(1): 28 - 30; DOI: 10.22359/cswhi_12_1_07 (C) Clinical Social Work and Health Intervention

Abstract:
Cited references: 2 
Change of the spectrum was caused by fire related psychotrauma and absence of housing for a week, until complementary sheltering facilities were arranged.

\section{Introduction}

Moria Refugee Camp for Syrian, Iraqi, Afghan and other Middle East refugees of war and economic migrants has been operating for 12 years with an original capacity of 2,000 migrants and refugees. However, since 2018, this capacity was exceeded 6-7 times. Arrival of the first Covid-19 positive individuals was reported on Sept. $2^{\text {nd }}$ followed by a forced quarantine of about 20 recently arrived migrants which caused unrest followed by fire destroying the original campus. Comparison of diagnoses of migrants and refugees arriving to the Moria Camps before and after fire destroying the original sheltering facilities on Lesbos Island. Upheavals and unrest after arrival of the first group of Covid 19 positive individuals discussed in this research pilot note.

\section{Methods}

This is a single setting single cohort study of the vulnerable refugee and migrant populations with the majority of Afghani Tajik Persian origin followed by Ethiopia and Sub-Saharan Africa nationals. This spectrum is very different from those arriving from Turkey in 2015-2018 where Iraqi and Syrian nationals were prevalent in $80 \%$ of arrivals. Two periods are compared concerning the spectrum of diagnosis-before the camp destroying fire (June to Sept.) and after the fire (Oct to Nov), causing 12,000 unsheltered and camping migrants including mothers, seniors and children for at least 5 days.

\section{Results and Discussion}

Table 1 analyses the spectrum of OPD admissions in our Outpatient Department inside the Moria UNHCR Camp and after the fire in mobile and sheltered OPD. In the first period until the fire outbreak, wounds and travel related injuries were commonest followed by: upper RTI due to overcrowding; with scabies as well due to lack of access to proper hygiene in the over populated camp.

After the devastating fire, psychosomatic related civilization diseases decompensated such as hypertension, diabetes and asthma, neurotic gastritis. Camping in nature for next 5 days led to outbreaks of RTI, wound and scabies related infections as a logic consequence of limited housing shelters.

\section{Conclusions}

The only positive feature of the devastating fire was a rapid transfer of unaccompanied minors to mainland Greece and other EU destina-

Table 1 Comparison of major diagnoses before and after the destroying fire in Lesbos Island UNHCR Camp Moria

\begin{tabular}{|ll|}
\hline \multicolumn{2}{|c|}{ Weekly admissions in OPD average 255............500 approx } \\
\hline Before the destroying fire & after the event (Oct - Nov) \\
\hline Wounds 51\% & $\begin{array}{l}\text { hypertension } \\
\text { diabetes decomp } \\
\text { asthma } \\
\text { psychomotoric gastritis }\end{array}$ \\
\hline Upper RTI 21\% & upper respiratory tract inf \\
\hline Scabies lice 19\% & $\begin{array}{l}\text { covid 19 } \\
\text { cabies, dental infection }\end{array}$ \\
\hline Gastritis 9\% & \\
\hline Dental infection 5\% & \\
\hline Two dg at once 5\% & \\
\hline
\end{tabular}


tions. The rest of the refugees were placed in provisional shelters and before winter shall be partially dispersed to the mainland to get better health care. The number of visits increased after the fire from 250 to 500 so the demand for health services increased by $100 \%$ due to non-communicable diseases related to stress such as coronary heart and neurologic diseases, psychoses, insomnia, depression, which may aggravate diabetes hypertension and asthma.

\section{References}

1. UNHCR ANNUAL REPORT BRANCH GREECE (2018) p. 145.

2. PERI H A, SUBRAMANIAN S, SLADECKOVA V, BYDZOVSKY J, DURCOVA B, KUBALIKOVA Z, OLAH M, MATULNIKOVA L, DOKTOROV A, BERESOVAA, KUBIK F, FULA M, OTRUBOVA J, KALATOVA D, KUKUCKOVA E, JURINOVA S, BENCA J, SHAHUM A, HOY LEANG HOINAND CHENG HOIN, SETA S/ Early detection of adverse therapy reaction in orphan children with AIDS (short communication) / In: Acta Missiologica. - ISSN 13377515. - Vol. 13, no. 2 (2019) p. 184-187. 


\title{
Understanding Pakhtun Woman's Vulnerability in Negotiation with their Husbands for HIV/AIDS Screening
}

\author{
N. Khan (Nasa Khan)1', W. Khan (Waseem Khan)², A. Naz (Arab Naz)2, A. Sultana \\ (Aneela Sultana) ${ }^{3}$, A. Pasha (Asmat Pasha) ${ }^{4}$
}

${ }^{1}$ University of Chitral, Pakistan.

${ }^{2}$ University of Malakand, Pakistan.

${ }^{3}$ Qaid-i-Azam University Islamabad, Pakistan.

${ }^{4}$ M. Phil Scholar, Khyber Medical University, Pakistan.

\section{E-mail address:}

nasar_s12@yahoo.com

\section{Reprint address:}

Nasar Khan

University of Malakand

Khyber Pakhtunkhwa

Pakistan

Source: Clinical Social Work and Health Intervention

Volume: 12

Pages: $32-39$

Cited references: 27

Issue: 1

\section{Reviewers:}

Vitalis Okoth

Hargeisa, Somalia

Johnson Mawole

Nyanza, Tanzani

\section{Keywords:}

Gender. Private Relationships. HIV/AIDS. Negotiation. Inequality. Migration.

\section{Publisher:}

International Society of Applied Preventive Medicine i-gap

CSWHI 2021; 12(1): 32 - 39; DOI: 10.22359/cswhi_12_1_08 CC Clinical Social Work and Health Intervention

\section{Abstract:}

Unequal treatment of females within families is a common phenomenon and is a core concern of feminist perspectives (Macionis, 2012; Haralambos \& Holborn, 2013). In patriarchal societies women are not welcome to discuss and negotiate with men (Thompson, 1998), and this pattern prevails in private relationships as well (Saunders et al. 2017). Framed under qualitative research design, this study aims to understand Pakhtun women's vulnerability in negotiation with their husbands for HIV/AIDS screening in Dir Lower, Khyber Pakhtunkhwa, Pakistan. Purposive sampling technique has been utilized to select samples from the population of interest whereby a total of 8 samples were se- 
lected in reaching the saturation point. For collection of the information, an interview guide was designed with relevance to the research questions of the current study. The collected information has been analyzed thematically. Findings show that women exercise limited sexual authority and men are in control when it comes to personal relationships. There is very much less space for women to discuss and negotiate with men regarding use of precautionary measures. Men consider discussion and negotiation as a competing behavior from women. Thereby women are apprehended of problems in marital relationships and angry reply from husbands in discussing and negotiating with men regarding private family relationships and use of precautionary measures. Men being vulnerable to HIV/AIDS in the study area due to high rate of emigration and inability of women to discuss and negotiate regarding screening tests and use of precautionary measures are increasing the spread of HIV/AIDS among families.

\section{Background of the Study}

The gender organization of the home is an eminent factor in constructing inequalities between men and women at familial level. It is embedded in access to material resources, power, and roles within the home (Ridgeway, 2011). Men and women confront each other on the basis of material resources, power, and roles within the home. It is evident from hundreds of studies that relatively men have more access to material resources, power, and play dominant and authoritative roles within the home (e.g. in patriarchal societies). As a result, men are the decision makers within the home, and there is very much less space for women to discuss and negotiate with men, and to make decisions (Thompson, 1998; Connell, 2009; Bowles, 2012).

\section{Women and Negotiation and Persuasion in private life}

There is a plenty of evidence the in a majority of societies that women are not allowed to negotiate with men i.e. negotiation about familial matters, health, having children, to go for work etc. This trend is very common in private life as well, for instance, a wife don't ask anything from her husband. It is evident that men do not like when women ask. A man considers it as a competing behavior, and perceives it in a negative way. This pattern of relationship does not allow women to discuss and negotiate with men (Thompson, 1998).

Gender roles play a key part here, for example, men's behavior and women's behavior is sig- nificantly influenced by the roles they play in their spective situation, culture or society. Men behave in an authoritative way because of their breadwinner role for the family (Lewis, 2009) while women take care of household responsibilities. In the majority of societies the status of male in family is authoritative because of their valued role as breadwinner whereas the female being a care taker of the household is not so valued. Concomitantly, women are not welcome to negotiate or discuss with men with regard to familial matters, health, having children, to go for work etc. Thereby, women often feel anxious which prevents them from negotiation. In this regard, for instance, a survey conducted revealed that women feel anxiety and discomfort while negotiating and persuading men. The key issue whereby women felt anxiety and discomfort included asking about things women want; changing residence; asking for starting a job or work; etc. Another imperative aspect in this context is negotiation apprehension. In explanation, women fear an inappropriate answer, ignoring behavior, and problems in relationships particularly when such negotiation is with husband (Allred, 1999; Babcock \& Laschever, 2003).

As mentioned in the previous paragraph a similar situation exists in Pakhtun culture and society. Pakhtun culture and society are predominantly patriarchal where men are in control e.g. at home and at the work place. Women are not given space to discuss their desires, decisions and opinions. Such desires, decisions and opinions 
are about deciding their mate selection or marriage, education, employment, family and children.

\section{Statement of the Problem}

A private relationship (e.g. marital) is an important aspect of an individual's family life. Unfortunately there is a bulk of evidence that women in private relationships are confronted with unequal treatment; subordinate position; imbalanced power sharing. As a consequence, there is a lack of space for women to discuss and negotiate with their husbands (Babcock \& Laschever, 2003). A similar situation has been found with regard to sexual relationships. For example, a study shows that women often don't ask their partners to use condoms. There are reasons for it, for instance, women are concerned that it may lead to marital problems such as it will damage their relationships with husband. Another reason is the role playing whereby men play the role of breadwinner for family which is more valued in society than that of women's role of taking care of household responsibilities. Consequently, women are anxious and apprehensive while discussing and negotiating with men regarding private life and sexual matters (Macionis, 2012; International Organization for Migration, 2006).

Literature indicates that differential power sharing, lack of discussion and negotiation in private and marital life has negative consequences. For example, study shows that lack of space for women to discus and negotiate with their husbands about the use of condoms during sex make women vulnerable to unwanted pregnancies, venereal diseases as well as viral and bacterial infections such as HIV, Gonorrhea, etc. (Lewicki, Saunders \& Minton, 1997: Babcock \& Laschever, 2003).

Emigration to Middle East and Gulf countries for the purpose of employment is a common phenomena in the Pakhtun belt of Pakistan (Zohry, 2007). Emigrants work in Middle East and Gulf countries for years and even a decade without their families and wives. Stress and sexual frustration commonly prevails among working emigrants which increases their vulnerability to have sexual affairs (e.g. paid sex) within countries of destination. 94\% of labor migrants are away from their spouses for a year or more than a year. Labor migrants are also not bound by the socio- cultural and religious norms which governs sexuality at the country of origin. Labor migrants are exposed to extreme working conditions and even sexual exploitation. The resulting isolation and stress may lead migrant workers to engage in behaviors, e.g. unsafe casual or commercial sex, which increase HIV risk. This risk is further worsening due to the inadequate access to HIV services and fright of being stigmatized for seeking HIV-related information and support (UNDP, 2004). As a consequences, migrants are at increased risk of being infected by sexually transmitted bacteria and viruses, for example, HCV, HIV, syphilis etc. (International Organization for Migration, 2006; National AIDS Control Program, 2017). Due to higher rates of migration to Middle East, United Kingdom and Malaysia, Pakistan are included in lists of countries whereby HIV/AIDS is spreading significantly. National AIDS Control Program (NACP) in its recent report of 2016-17 there are 22,333 registered cases of HIV/AIDS in Pakistan and an estimated 0.133 million individuals are infected by HIV virus in Pakistan. Therefore, it is important on return to have a screening test and use precautionary measures to prevent the further spread of HIV/AIDS. In this regard, wives could play an eminent role to persuade their husband to have screening in order to stop further spread of HIV/AIDS. However, in light of the mentioned literature on gender related sub-ordination women often are unable to discuss and negotiate sexual matters with husbands. In this connection, this study is an effort to understand Pakhtun women's vulnerability in negotiation with their husbands for HIV/AIDS screening

\section{Theoretical Framework}

Negotiation is an essential component of human interaction. Negotiation during interaction is a part of micro level phenomenon (e.g. concerning everyday life) such as household interaction; work place interaction; interaction in Church or Mosque; etc. Similarly, in terms of relationships across sex and gender negotiation is an integral component (Weini \& Kashuba, 2012). However, studies show that there is deference in negotiation patterns across gender, for instance, women are constrained to negotiate with men. There are reasons for it which includes lack of access to resources, gender stereotypes and social 
roles. Each of the mentioned factors affects negotiation across gender in its own manner. Firstly, in patriarchal society men dominates the economic sphere of life and have access to material resources while on the other hand women are oppressed. Second, gender stereotypes, for example, considering women as less competent and unable to think rationally and logically makes women incapable to negotiate with men. Third, social role such as men being the breadwinners for family contributes significantly constrain women to discuss and negotiate with men (Macionis, 2012).

Feminist perspective emerged during 1950s, and successfully explains inequalities on familial basis across gender. Feminist perspective explains two prominent reasons of women's oppression in family; first, female are socialized in a way that they must adopt subservient roles within the family while on the contrary male are socialized to act and behave in superior way. Second, females are socialized in way to develop into a housewife, for example, taking care of children, cooking, providing emotional support, and indeed, these are defined as the only way to be feminine or woman. Thereby, feminist perspective considers family as the root cause of gender inequalities existing in society i.e. inequalities in family, education, workplace, Church or Mosque etc. For further details in this regard see Haralambos \& Holborn (2013, Chapman et al (2015).

\section{Objective of the Study}

The prominent objective of the current study is to recognize the inability of Pakhtun Women to negotiate and discuss with their husbands about HIV screening test and using precautionary measure upon return from the country of destination.

- This study is based on following research questions:

- What is the status of women with regard to sexual power in home?

- How much space and opportunity is given to women to discuss and negotiate with their husbands regarding sex and use of precautionary measures?

- What anxieties prevail among women while having discussion and negotiation with husbands about HIV screening?

- How and why women are apprehensive to dis- cuss and negotiate with husbands about HIV screening and use of precautionary measures?

\section{Material and Methods}

Study Area: This study has been carried out in Chakdara, District Dir Lower, Khyber Pakhtunkhwa, Pakistan. Dir Lower is one the areas where HIV/AIDS is spreading, and most importantly it is spreading hidden. Currently a project is working on the issue which reported there are 5,999 registered cases of HIV/AIDS in Dir Lower.

Nature of the Study: The study is framed under qualitative research design a textual representation of the information e.g. in words, and focuses on indepth understanding of an issue. For further details on qualitative research design see Nueman (2006).

Sampling: Purposive sampling technique has been utilized for the current study whereby a total of 9 women were sampled. The determination of sample size was based on the saturation point. For further details on saturation point see Saunders, Sim, Kingstone, Baker \& Waterfield et al (2017). Besides, the purposeful sampling criteria was:

- Selection of women whose husbands are/were working in Middle East

and Gulf countries for one year at least.

- The selected women should be aware of HIV/AIDS and its mode of transmission.

Data Collection: An interview guide was designed with relevance to the research questions of the current study to collect information from the sampled women. For, detailed descriptions on an interview guide as a tool for data collection see Boyce \& Neale (2006).

Data Analysis: The collected information has been transcribed and discussed thematically. For thematic method of data analysis see The University of Auckland Guide on thematic analysis.

Ethical Considerations: The issue discussed in the current study is a sensitive one. Therefore, a coding mechanism has been devised in order to keep the respondents anonymous. Respondents are presented by $\mathrm{R}$ for denoting respondents, the first alphabet of their name and then interview number. For example, John Mathew whose interview is on first number will be denoted as R-J-1. The complete list of respondents is given in the following table: 


\begin{tabular}{|c|l|c|}
\hline S. No & $\begin{array}{l}\text { First alphabet of } \\
\text { respondents name }\end{array}$ & Code \\
\hline 1 & Z & R-Z-1 \\
\hline 2 & N & R-N-2 \\
\hline 3 & N & R-N-3 \\
\hline 4 & K & R-K-4 \\
\hline 5 & A & R-A-5 \\
\hline 6 & H & R-H-6 \\
\hline 7 & M & R-M-7 \\
\hline 8 & R & R-R-8 \\
\hline 9 & S & R-S-9 \\
\hline
\end{tabular}

\section{Data Analysis: 1.6.1 Transcription}

Field information shows that women's status is very low with regard to exercise of sexual matters and private life. Men exercise sexual powers with regard to private life, and women have very limited powers. Respondents stated that men are in control when it comes to decisions regarding private life similar to other household matters whereby men are in control. A respondent illustrated that:

„....the status of man is similar in private life as to that of other household matters ...." (R-N-2)

Another respondent argued that:

„,....my husband make decision where it is about household matters or whether it is private life such as having children...." (R-R-8)

Findings indicate that there is very much less space for women to discuss and negotiate with husbands regarding sex and use of precautionary measures. The majority of the respondents (e.g.R-N-2, R-K-4, R-M-7, R-A-5, R-H-6 and R$\mathrm{R}-8$ ) opined that it is considered as a stigma if they discuss such things with their husbands. Husbands are in control about having sex and use of condom. For instance, a respondent said that:

„....husband does not appreciate such discussion. They want to be authorities in this regard (sexual discussion and negotiation) as well..." (R-H-6)

With regard to discussion and negotiation of precautionary measures a respondent stated that:

„....my husband and all of the men in this area do not like use of precautionary measures while having sex. They are ignorant and also do not like any discussion in this regard because they consider it as a competing behavior ...." (R-K-4).
Findings enumerates that women cannot ask there husband about having HIV/AIDS test on return to home. A respondent stated that:

„I cannot imagine having a discussion with my husband about screening test for HIVIAIDS “ (R-M-7).

Another woman replied that:

„... it is too difficult for me to ask my husband to have screening test for the disease...." (R-S-9).

Woman are apprehensive while discussing sex related issues with their husbands including precautionary measures such as use of condoms and screening tests for sexually transmitted diseases. Such apprehension is because of patriarchal social structure and prevailing anxieties among women in the study area.

Pakhtun society is predominantly patriarchal in nature where women are not used to ask or discuss issues, decision and opinion with their husbands. A respondent stated that:

„....husbands and male members of the family are respected and not asking them is considered as respect there. We respect their dominancy as well, and therefore we do not ask them in sexual matters as well...." (R-Z-1).

„....How can I ask my husband to have HIV/AIDS screening test. I had no such discussion with him previously, and he will not respond to it even if I had...." (R-K-4).

Another woman argued that:

„....In our family there are many emigrants to Saudi Arabia, and I am sure that no women can tell her husband for HIVIAIDS test. We (women) are not allowed to discuss our opinions with men in our family...." (R-N-2).

Women fear of Husband's reply (apprehension), for example, replies include doubt on the character of the husband reply that he is there for labor not for sex. And most important is the husband's reply that I am staying and working there to earn for family and you are persuading me to have HIV/AIDS test.

In this regard, a woman replied that:

„....my husband will be very angry if ask for HIVIAIDS test. He is there to earn for the family, and persuading him for a test will make him angry...." (R-Z-1).

A woman stated that:

„....my husband response will be very aggressive, and he will be straight forward that I doubt his character...." (R-R-8). 
A woman answered that:

„....once I had a disagreement with my husband regarding our children's education. He replied that I am here (mentioning country of destination) and facing hardships to earn money for you. Keeping his reply in this context, if I ask him to have HIVIAIDS test, his reply will be the same and even harsher...." (R-R-8).

Most importantly women fear of marital problems resulting from such negotiation and discussion. In this regard, an extract from an interview is:

„,...I want to have a discussion with my husband about certain issues but I cannot because for sure it will lead to disagreements and problems among us. And I cannot afford it because in this culture husbands are the source of social support and prestige for women...." (R-S-9).

\subsubsection{Discussion}

In patriarchal societies similar to other aspects men are in control of sexuality as supported by Babcock \& Laschever (2003). Women are provided with minimal space for discussion and negotiation with men regarding sexual matters. Therefore, woman exercise very limited sexual authority, and men control their sexual behaviors and decisions. The prominent aspects of sexual authority includes having children; deciding the number of children; use of condoms; other precautionary measures such as screening tests for sexually transmitted diseases (STD's). In this connection the studies of Thompson (1998), Ridgeway (2011), Babcock \& Laschever (2003) also state that men are in control in private relationships (e.g. marital relations) and there is minimal space for women to discuss and negotiate with husbands.

With regard to the current study, it is important to mention that emigration from Pakistan to the Gulf, Middle East and Malaysia is very common for the purpose of employment as supported by Zohry (2007). Men stay in the mentioned countries for months and years with families. As a result, work stress and sexual frustration prevails among such men, and they are vulnerable to sexual affairs (e.g. paid sex) which increase their vulnerability to sexually transmitted diseases (STD's) as well. In this context, International Organization for Migration (2006) enumerates that stress and sexual frustration prevail significantly among labor migrants, and therefore have a tendency to get involved in risky sexual behaviors which make them vulnerable to sexually transmitted diseases (STD's). In addition to it, Weini \& Kashuba(2012) assert that people remaining absent from home for long times including labor migrants are at risk of HIV infection. Keeping this in view, statistics from a local organization working on HIV/AIDS in Malakand division shows that there are 5,999 registered cases in Dir Lower, Khyber Pakhtunkhwa, Pakistan, and a major portion of which is emigrants. Therefore, screening tests upon return can prevent the spread of the disease up to some extent.

However, the study area is pre-dominantly patriarchal supported by Nazet al (2012) and men are in control of every aspect of life including private and sexual life. As a result, numerous anxieties prevail among women apprehending them to discuss and negotiate about sexual matters with husbands. These anxieties in particular include expecting negative replies from husbands. For instance, a husband can reply about doubt of his character, and emotional replies as well can lead to marital problems. In this regard, the study of UNAIDS (2012) indicates that unequal cultural, social and economic status and unaccommodating attitudes towards sex among men is a significant contributing factor in HIV spread among women in African countries.

\subsection{Conclusion}

Pakhtun society is patriarchal where women are not allowed to discuss their opinions and desires. Emigration to Middle East and Gulf countries is common among the Pakhtun belt, and due to spending many years in destination countries, emigrants are vulnerable to have sexual affairs which increases their vulnerability to STD's including HIV/AIDS. Therefore, it is important to have HIV/AIDS screening test on return. However, women are unable to discuss it with husbands due their subordinate position in society, husband aggressive response, and marital problems.

\section{References}

1. ALLRED K (1999) Anger and retaliation: Toward an understanding of impassioned conflict in organizations. Research on Negotiation in Organizations: 7 (27). 
2. BABCOCK L, LASCHEVER S (2003) Women don't Ask: Negotiation and Gender Divide. Princeton University Press, 41 William Street, Princeton, New Jersey 08540.

3. BABCOCK L, GELFAND D S, STAYN H (2002) Propensity to initiate negotiations: A new look at gender variation in negotiation behavior. Carnegie Mellon Univ.

4. BOWLES R H (2012) Psychological Perspectives on Gender in Negotiation. Harvard Kennedy School (HKS) Faculty Research Working Paperseries at: http://web.hks.harvard.edu/publications.

5. BOYCE B, NEALE P (2006) Conducting InDepth Interviews: A Guide for Designing and Conducting In-Depth Interviews for Evaluation Input. Pathfinder International. Online Available at: http://www2.pathfinder.org/site/ DocServer/m_e_tool_series_indepth_interviews.pdf.

6. CHAPMAN et al. (2015) A Level Sociology Student Book One. Collins. ISBN-10: 0007597479.

7. CONNELL R (2009) Gender Polity Publications.

8. GUEST G, MACQUEEN N (2012) Applied Thematic Analysis. Sage Publications.

9. HARALAMBOS M, HOLBORN J (2013) Sociology Themes and Perspectives. Collins. ISBN-10: 0007597479.

10. INTERNATIONAL ORGANIZATION FOR MIGRATION (2006) Briefing note on HIV and Labor Migration in MOZAMBIQUE www.iom.org.za.

11. PERI H A, SUBRAMANIAN S, SLADECKOVA V, BYDZOVSKY J, DURCOVA B, KUBALIKOVA Z, OLAH M, MATULNIKOVA L, DOKTOROV A, BERESOVA A, KUBIK F, FULA M, OTRUBOVA J, KALATOVA D, KUKUCKOVA E, JURINOVA S, BENCA J, SHAHUM A, HOY LEANG HOINAND CHENG HOIN, SETA $\mathrm{S} /$ Early detection of adverse therapy reaction in orphan children with AIDS (short communication) / In: Acta Missiologica. ISSN 1337-7515. - Vol. 13, no. 2 (2019) p. 184-187.

12. IRWIN / MCGRAW-HILL. ISAKSEN J, SONGSTAD G N, SPISSOY A (2002) Socioeconomic effects of HIV/AIDS in African countries. ChrMichelsen Institute Norway.
Online Available at: www.cmi.no/public/pub 2002.

13. KRCMERY V, BUCKO L, KIMULI D, JACKULIKOVA M, KOZON V, OLAH M, KOVAC R, JANCOVIC M, HOLKOVA J, MIKOLASOVA G, BOZIK J, POLONOVA J, MRAZOVA M, SUVADA J, KOSTICOVA M, HAJDENOVAZ. Cohortation and testing of elderly homeless within COVID pandemics in an urban environment - example of a life island mission model. In: Acta Missiologica. - ISSN 2453-7160 (online) / ISSN 13377515 (print). - Vol. 14, no. 1 (2020) s. 76-78.

14. LEWICKI, R., SAUNDERS, D., MINTON. J. (1997). Essentials of negotiation. Boston, MA.

15. LEWIS J (2009) Work-Family Balance, Gender and Policy. Edward Elgar Publishing, Inc. William Pratt House 9 Dewey Court Northampton Massachusetts 01060 USA. Macionis, J. J. (2012). Sociology. Pearson Publications India.

16. NATIONAL AIDS CONTROL PROGRAM (2017) Online Available at: http://www.nacp. gov.pk/.

17. NAZ A, DARAZ U, MUGHAL I, ALAM A, KHAN W, HUSSAIN M (2012) Pakhtun Social Structure and its Impacts on Women's Education. Global Journal of Human Social Science Linguistics \& Education, Vol. 12 (13).

18. NUEMAN L (2006) Quantitative and Qualitative research methods $\left(6^{\text {th }}\right.$ edi). Pearson Publications India.

19. RIDGEWAY C (2011) Framed by Gender: How Gender Inequality Persists in the Modern World. Oxford University Press, Inc.198 Madison Avenue, New York, New York 10016.

20. RILEY H C, L BABCOCK, MCGINN $\mathrm{K}$ (2003). Gender as a situational phenomenon in negotiation. Carnegie Mellon University.

21. SAUNDERS B, SIM J, KINGSTONE T, BAKER S, WATERFIELD J, BARTIAM B, BURROUGHS H, JINKS C (2017) Saturation in qualitative research: exploring its conceptualization and operationalization. Quality and Quantity: 52 (4).

22. THE UNIVERSITY OF AUCKLAND (no date). About thematic Analysis. Online Avail- 
able at: https://www.psych.auckland.ac.nz/ en/about/our-research/research-groups//thematic-analysis/about-thematic-analysis.html.

23. THE WORLD BANK (2005) HIV/AIDS in Pakistan. Online Available at:www.worldbank.org/saraids.

24. THOMPSON L (1998) The mind and heart of the negotiator. Upper Saddle River, N.J.: Prentice.

25. UNAIDS (2012) Feature Story: HIV increasingly threatens women in Eastern Europe and Central Asia. Online available at:http://www. unaids.org/en/resources/presscentre/featurestories/2012/march/20120312alaskerwomeneeca.

26. WEINI M S, KASHUBA B A (2012) Labor Migration and HIV Risk: A Systematic Review of the Literature. AIDS Behav. Vol; 16(6): 1605-1621.

27. ZOHRY A (2007) Migration and Development in Egypt. Institute for Migration and Cultural Studies (IMIS) Osnabruck University, Germany. 


\title{
One Month or Real Life in a Single Clinic near the Slum Area in Mukuru Urban setting in the Time after COVID-19 Epidemic in Kenya
}

\author{
D. Kimuli (Daria Kimuli) ${ }^{1}$, M. Bartkovjak (Marian Barkovjak)³, D. Barkasi (Daniela \\ Barkasi) $)^{4}$, V. Sladeckova (Veronika Sladeckova) ${ }^{3}$, L. Roman (Ladislav Roman)5, \\ L. Radkova (Libusa Radkova)6 ${ }^{6}$, V. Krcmery (Vladimir Krcmery)³, M. Palockova \\ (Monika Palockova)², V. Namulanda (Victor Namulanda) ${ }^{7}$
}

${ }^{1}$ St. Philip Neri Primary School, Joska a St.Kizito Vocational centre, Original Article Utawala, Kenya.

${ }^{2}$ St. Francis School Sisters, Fier, Republic of Albania.

${ }^{3}$ Slovak Tropical Institute Slovak Med Univ SZU Bratislava Branch Nairobi Rep of Kenya Sisters of Mercy, Mukuru Nairobi.

${ }^{4}$ Bl. D. Trcka Inst, Michalovce.

${ }^{5}$ St. P. Pio Institute Piestany.

${ }^{6}$ St. Lesley college, Nové Zamky and MPC Nairobi.

${ }^{7}$ St. Philip Neri \& St. John Paul II School of Missiology PhD Program Nairobi.

\section{E-mail address:}

pechacova.daria@gmail.com

\section{Reprint address:}

Daria Kimuli

St. Philip Neri Primary School, Joska a St.Kizito Vocational centre Utawala

Kenya

Source: Clinical Social Work and Health Intervention

Volume: 12

Issue: 1

Pages: $40-43$

Cited references: 2

\section{Reviewers:}

Andrea Shahum

Chapel Hill NC, USA

Claus Muss

IGAP Zurich $\mathrm{CH}$

\section{Publisher:}

International Society of Applied Preventive Medicine i-gap

\section{Keywords:}

Covid-19 in Kenya.

CSWHI 2021; 12(1): 40 - 43; DOI: 10.22359/cswhi_12_1_09 (C) Clinical Social Work and Health Intervention 


\section{Abstract:}

\section{Introduction}

Three major reasons for disease or injury related mortality in Sub-Saharan Africa included within last 30 years HIV, tuberculosis and malaria followed by malnutrition, perinatal maternal and neonatal deaths and malnutrition. This was the spectrum what our teams have observed in 1999-2012 in Mukuru Mary Immaculate Center Outpatient Department, Pharmacy and Laboratories in Mukuru, Nairobi(1). When before 2000, malaria HIV, TB and STDs were the commonest diseases followed by multiple parasitic related anemia, after active screening and education against HIV, the situation changed. Here we assess the situation as a real life pilot 20 years later just after the Covid-19 first wave hit Kenyan health care system in the Summer of 2020.

\section{Methods}

This descriptive pilot study showed that the commonest diseases as a spectrum of OPD admissions in October 2020 as an analysis of 1,237 patients in 30 days after Covid-19 left the first wave in the Summer in East African community states. Mary Immaculate Center has two OPDs one for children and one for adults in addition to a biochemical, laboratory, HIV testing VCT, parasitological laboratory and pharmacy with a daily capacity for about 100 OPD children and adults, one Slovak Doctor, 4 Kenyan nurses, 2 lab technicians, one anti-malnutritional health officer and 2 local VCT experts working for HIV prevention.

\section{Results and discussion}

Tables $\mathbf{I}$ and 2 represent the number and gender of admissions per month, for October the first month the clinic fully operated after the partial lockdown due to Covid-19 pandemics. Monthly patient flow in October 2020 including 1,237 individuals, children and adults with a weekly flow of 203-365. (Tab 1). Commonest diseases include urinary tract infections 116 cases, gastroenteritis 110, non-specified diarrhea 26, upper RTI 77, pneumonia 27, helmints 28 (screening for anemia, diarrhea and malnutrition).

An anti-malnutrition program was run in a separate building for a specific group of mothers, as well as VCT for those who were willing to stay anonymously and get not only testing but also counselling for the disease.

Child patients also received onsite medication for 5-10 days, all for one symbolic payment (about 1.5 euro per doctors check, lab, medication and second check) because the major part of the attending patients were from the slum areas of Mukuru and St. Catherine.

When comparing those results from the fall 2020 to results of the first group of doctors(2) in $1999-2009$, HIV prevalence was up to $20 \%$ in males and $25 \%$ in females, after HIV the second commonest were other sexually transmitted diseases, respiratory tract infections including pneumonia in children and youngsters, following by cuts injuries and wound infections.

Nowadays, UTI and gastroenteritis are the leading cause of morbidity, while the proportion of HIV decreased substantially by $5-12 \%$ and STD s also dropped to a lower proportion. 


\section{Conclusions}

The comprehensive treatment screening and educational program in health care focused against major killers in Sub-Saharan Africa HIV, TB and malaria, followed by STD are decreasing and being replaced by other infectious (gastritis due to insecure water, respiratory tract infections due to wrong cooking practices in slum huts), Ian interesting observation was also an increase of non-infectious diseases probably due to increasing life expectancy due to decline of HIV and TB, such as hypertension, asthma, diabetes etc.

PATIENTS TREATED IN OCTOBER

\begin{tabular}{|l|l|l|l|l|l|}
\hline $\begin{array}{l}\text { TYPE OF } \\
\text { PATIENT }\end{array}$ & GENDER & \multicolumn{4}{|l|}{ AGE IN YEARS } \\
\hline & & $0-5$ & $6-13$ & $>13$ & TOTAL \\
\hline $\begin{array}{l}\text { NEW } \\
\text { REGISTRATION }\end{array}$ & MALE & 72 & 23 & 198 & 293 \\
\cline { 2 - 7 } & FEMALE & 56 & 27 & 211 & 294 \\
\hline $\begin{array}{l}\text { REVISIT } \\
\text { REGISTRATION }\end{array}$ & MALE & 108 & 28 & 149 & 285 \\
\cline { 2 - 7 } & FEMALE & 94 & 26 & 245 & 365 \\
\hline
\end{tabular}

\section{Spectrum of diagnoses}

\begin{tabular}{|l|c|}
\hline $\begin{array}{l}\text { MOST COMMON } \\
\text { DIAGNOSIS }\end{array}$ & NU of P. \\
\hline $\begin{array}{l}\text { Acute upper respiratory } \\
\text { infections unspecified }\end{array}$ & 2619 \\
\hline Others & 2833 \\
\hline Gastroenteritis & 1831 \\
\hline Urinary tract infections & 1875 \\
\hline Respiratory tract infections & 453 \\
\hline Fever unspecified & 497 \\
\hline $\begin{array}{l}\text { Gastritis unspecified / } \\
\text { peptic ulcer disease }\end{array}$ & 574 \\
\hline Neuralgia \&neuritis unspecified & 407 \\
\hline $\begin{array}{l}\text { Abdominal pregnancy } \\
\text { unspecified }\end{array}$ & 546 \\
\hline Allergy unspecified & 119 \\
\hline Diabetes / Hypertension & 433 \\
\hline Skin infections & 207 \\
\hline Wounds & 123 \\
\hline Headache & 90 \\
\hline Myalgia & 55 \\
\hline
\end{tabular}

TOTAL NUMBER OF PATIENTS: 1237

\section{TOP DIAGNOSIS IN OCTOBER}

\begin{tabular}{|l|l|l|l|l|}
\hline & DIAGNOSIS & FEMALE & MALE & TOTAL NO OF CASES \\
\hline $\mathbf{1 .}$ & Other diseases & 270 & 176 & 446 \\
\hline $\mathbf{2 .}$ & Urinary Tract Infections & 40 & 76 & 116 \\
\hline $\mathbf{3}$ & Gastritis & 50 & 60 & 110 \\
\hline $\mathbf{4 .}$ & Cough & 36 & 41 & 77 \\
\hline $\mathbf{5 .}$ & Abdominal Pregnancy & 56 & 0 & 56 \\
\hline $\mathbf{6 .}$ & Myalgia & 18 & 37 & 55 \\
\hline $\mathbf{7 .}$ & Febrile illness & 36 & 17 & 53 \\
\hline $\mathbf{8 .}$ & Acute Upper Respiratory Infections & 15 & 24 & 39 \\
\hline $\mathbf{9 .}$ & Helminthiasis & 12 & 16 & 28 \\
\hline $\mathbf{1 0 .}$ & Diarrhoea (unspecified) & 15 & 11 & 26 \\
\hline $\mathbf{1 1 .}$ & Acute Lower Respiratory Infections & 13 & 11 & 24 \\
\hline $\mathbf{1 2 .}$ & Headache & 8 & 15 & 23 \\
\hline $\mathbf{1 3 .}$ & Acute diarrhoea & 10 & 10 & 20 \\
\hline $\mathbf{1 4}$. & Candindiasis & 15 & 0 & 15 \\
\hline $\mathbf{1 5}$. & Abrasion wounds) & 9 & 3 & 12 \\
\hline
\end{tabular}

\section{TB CLINIC REPORT}

We had 12 TB patients, 1 new case during the month, two were on supplementary foods.

\section{MCH REPORT}

Antenatal mothers were 68 while immunized children were 141. 


\section{Number of patients by months}

\begin{tabular}{|l|r|}
\hline February & 1364 \\
\hline March & 1574 \\
\hline April & 1006 \\
\hline May & 1340 \\
\hline June & 1252 \\
\hline July & 909 \\
\hline August & 1142 \\
\hline September & 1065 \\
\hline Oktober & 1237 \\
\hline Spolu & $\mathbf{1 0 8 8 9}$ \\
\hline
\end{tabular}

\section{References}

1. WHO ANNUAL REPORT-SUB-SAHARAN AFRICA (2017) World health Organization Geneve, 2017. 265 pp

2. UNITED NATIONS AIDS PROGRAM (2015) UN New York, UN Publishing House, 2015. $145 \mathrm{pp}$ 


\section{An Analysis of Anthropometric Measurements of Children Enrolled in Programs for Managing Acute Malnutrition, in Kwale County, Kenya}

\section{Z. Kralova (Zuzana Kralova)'1 D. Jakubcova (Denisa Jakubcova)', V. O. Okech (Victor Otieno Okech)², A. Ondrusova (Adriana Ondrusova) $)^{1,3}$}

${ }^{1}$ Trnava University in Trnava, Faculty of Health Care and Social

Work, Slovakia.

${ }^{2}$ Comenius University in Bratislava, Department of Social Work, Slovakia.

${ }^{3}$ Faculty of Healthcare, Alexander Dubcek University of Trencin, Slovakia

\section{E-mail address:}

aondrusova@gmail.com

\section{Reprint address:}

Adriana Ondrusova

Trnava University in Trnava

Faculty of Health Care and Social Work

Trnava

Slovakia

Source: Clinical Social Work and Health Intervention

Volume: 12

Pages: $44-53$

Cited references: 18

\section{Reviewers:}

Andrea A Shahum

Chapel Hill NC, USA

Jarmila Holkova

Malindi

\section{Publisher:}

International Society of Applied Preventive Medicine i-gap

\section{Keywords:}

Anthropometric Measurements. Kenya. Malnutrition.

CSWHI 2021; 12(1): 44 - 53; DOI: 10.22359/cswhi_12_1_10 C C Clinical Social Work and Health Intervention

\section{Abstract:}

Introduction: Malnutrition remains an important public health challenge in developing countries. Approximately, each year, 3 million children below 5 years old die due to malnutrition. Evidence-based nutrition programs depend on accurate estimates of malnutrition derived from anthropometric data collected from nutrition centers for therapeutic feeding. Anthropometric information can be used to determine an individual's nutritional status and prevalence of malnutrition, and subsequently provide 
the essential medical and nutritional care for children as a part of the management of malnutrition. Aim of our study was to track progress of anthropometric measurements of malnourished children enrolled in therapeutic feeding programs from the point of admission up to a period of four months.

Methods: This was an observational cohort study or 7 months for 227 malnourished children admitted to the therapeutic feeding program in Kwale County, Kenya. Anthropometric measurements were taken at admission, $1^{\text {st }}, 2^{\text {nd }}, 3^{\text {rd }}$ and $4^{\text {th }}$ months in the program. Progress of WAZ, HAZ, MUAC and WHZ of malnourished children were later analysed using WHO AnthroPlus.

Results: At admission, $30 \%$ of children were at risk of malnutrition; $34 \%$ of children with moderate to acute stages of malnutrition; $36 \%$ of children suffering from severe acute malnutrition. In the course of the therapeutical feeding program, protein food supplements were provided to the child and family as such. This led to a decrease in prevalence of severe acute malnutrition of $19 \%$ after 4 months in the nutritional program. Progress in all anthropometric parameters after 4 months were reported, with these median values: WAZ $\mathrm{z}$-score (-2.81 to -1.15$)$; HAZ z-score (-2.35 to 1.00$)$; MUAC z-score (2.47 to -1.68$)$; WHZ z-score (-2.22 to -0.71$)$.

Conclusion: We conclude that anthropometric measurements of children significantly improves after four months of intensive therapeutic feeding of malnourished children. In this study the results indicate that comprehensive care for malnourished children, which includes: correct and accurate anthropometric measurements; providing treatment; regular monitoring of the children; collaboration with caretakers of the children, with health workers in the rural health facilities; with community health workers in communities lead to improved child nutrition.

Keywords: Malnutrition, Therapeutic feeding, Wasting, Stunting, Underweight, MUAC, Anthropometry.

\section{Introduction}

The World Food Program defines malnutrition as a state in which the physical function of an individual is impaired to the point where he or she can no longer maintain adequate bodily performance processes such as: growth; physical work; resisting or recovering from disease ${ }^{1}$. Malnutrition is a global health issue especially for children under 5 years of age who are in significantly higher risk of mortality and morbidity than well-nourished children ${ }^{2}$. Malnutrition, more specifically undernutrition, is a global health issue; it is one of the leading causes of morbidity and mortality among children below the age of 5 years. It contributes to at least $45 \%$ of mortalities in children below the age of 5 years ${ }^{3,4}$.

It is estimated that 50.5 million children under 5 years of age worldwide suffered from acute malnutrition; 150.8 million children under 5 are affected by chronic malnutrition; 20 million babies are born of low birth weight each year; 38.3 million children under 5 are overweight ${ }^{3,5}$. The majority of children under 5 years of age, who suffer from acute malnutrition, live in SubSaharan Africa and in South Asia ${ }^{6}$.

The need for better nutrition was recognized in the Sustainable Development Goal (SDG) 2, adopted by the UN in 2015 which aims to zero hunger and improve nutrition. This SDG provides global and national impetus to address malnutrition and expedite progress.

Acute and chronic malnutrition is measured and quantified through anthropometry, which is constituted by the basic data - age, sex, weight, height, length, edema, MUAC. Separate indices in most circumstances are constructed of weightfor-height, height-for-age and weight-for-age ${ }^{1}$. For statistical reasons, WHO recommends using the Z-scores (standard deviation scores), which means that measurements of a study population should be related to the reference population ${ }^{7}$. All these measurements are the key building blocks of anthropometrics and are essential for classifying nutritional status in children under 5 years of age $^{1}$.

In Kenya, malnutrition remains one of the most serious health issues among children under 5 years of age. Kenya has $26 \%$ of children under 5 with chronic malnutrition; $4 \%$ with acute malnutrition; $11 \%$ are underweight ${ }^{8}$. Kenya Demo- 
graphic and Health Survey further reports that infant mortality rate stands at 39 deaths per 1,000 live births, and a mortality rate of 52 deaths per 1,000 live births for children below the age of 5 years. At these levels, about one in every 26 Kenyan children dies before reaching age 1; about one in every 19 does not survive to his or her fifth birthday ${ }^{8}$. In regions where food security and natural disasters have affected the population, rates of acute malnutrition in under 5 are higher ${ }^{2}$.

According to the 2009 Kenya Demographic and Health Survey (KDHS), Coast Province, particularly Kwale County, one of the 47 Counties in Kenya, had a higher rate (39\%) of malnutrition among children under 5 years of age than the national average; the second highest in the country. The 2014 Kenya Demographic and Health Survey (KDHS) shows that this has reduced over the years and was reported to be at $29.7 \%$ but was still the second highest in the country ${ }^{9}$. To improve health status of malnourished children under 5, Trnava University from Slovak Republic, established 3 nutrition centers in selected areas within Kwale County, because of the highest rate of malnutrition in children under 5 years of age and also the second factor of areas selection was the logistical location of the centers due to accessibility from the surrounding communities.

Nutrition Centers, were established in Matuga Sub-county in Kwale County, were housed at Kwale Sub-county Hospital, Mkongani Health Center and Tiwi Rural Health Training Center in 2012. These provide medical, social and counselling services for malnourished children and their caretakers, through the diagnostic and treatment of malnutrition, provision of adequate complementary food (porridge, vitamin supplements, beans) as well as education of caretakers on child care and their health contribute to improving quality of life of their families and communities as a whole. Community Management of Acute Malnutrition (CMAM) as a proven approach to manage acute malnutrition in children under five ${ }^{10}$, we implemented in our therapeutic feeding programs in Kwale Region. We trained 50 community health volunteers to do community-based mobilization, screening, follow-up, counselling and education, which increases coverage, access, and effectiveness of treatment for acute malnutrition.

The objective of our study is to describe fac- tors putting a child in higher risk of being malnourished; to find prevalence of moderate and severe acute malnutrition at admission and then after 4 months in the nutritional program; mainly to follow progress of anthropometric parameters when a child and family are supported by protein food supplements and checked regularly.

\section{Methods}

\section{Study groups}

In 2012, Trnava University from the Republic of Slovakia, through cooperation with the Ministry of Health, Kenya, established 3 nutrition centers for therapeutic feeding in Kwale County, Kenya. The mission of the three nutrition centers was to provide nutrition care to malnourished children aged between 6 and 59 months. The nutrition care provided included: weekly growth monitoring; promotion and provision of therapeutic diets; supplementation of vitamin A and minerals; support group for pregnant and lactating mothers. Medical care, in partnership with local hospitals, was also provided to malnourished children. Medical care included treating of illnesses associated with malnutrition, deworming and immunization.

The 3 feeding centers had 2 nutrition programs: a) Supplementary Feeding Program (SFP) for children who were moderately malnourished; b) Outpatient Therapeutic Feeding Programs (OTP) for the severely malnourished children.

Moderately malnourished children enrolled in the SFP were provided every fortnight with $3.5 \mathrm{~kg}$ of Corn Soy Blend (CSB) porridge or sachets of Plumpy soy and their anthropometric measurements taken for purpose of monitoring their growth on every visit to the center. Children who were admitted into the SFP were those who had a MUAC between 11.5-12.4 cm, and/or with a Weight for Height Z (WHZ) score <-2 SD to > -3 SD. Moderately malnourished children would be discharged from the SFP once their MUAC was greater than $12.5 \mathrm{~cm}$ or their WHZ was greater than -2 SD for 2 consecutive visits, or had defaulted from the program for more than 3 consecutive visits.

Severely malnourished children who were enrolled in the OTP were provided with Ready to Use Therapeutic Food (RUTF), for our program we used Plumpy nuts which were provided to the 
severely malnourished on a weekly basis based on their weights. The minimum number of Plumpy nut sachets a child could be given per week was 11 to a maximum of 35 sachets. Each Plumpy nut sachet provided 500 kcals. In addition, the severely malnourished children were also provided with clinical care, where their underlying illnesses were promptly treated. Admission criteria into OTP were based on MUAC < $11.5 \mathrm{~cm}$, were older than 6 months, or their WHZ was <-3 SD, had bilateral pitting edema Grade 1 or/and had poor appetites. Children who could not eat more than half sachet of Plumpy nut were considered to be having poor appetite and were referred for inpatient care. They were discharged from the program as cured once their MUAC was greater than $11.5 \mathrm{~cm}$ or their WHZ was $-2 \mathrm{SD}$ and had no pitting edema for 2 consecutive visits. They would also be discharged from OTP as defaulters when they failed to attend their appointments for 3 consecutive visits. Severely malnourished children once discharged from OTP would automatically be admitted into SFP.

\section{Data collection}

Data for the research was collected through a screening program in the 3 feeding centers, conducted between September 2019 to March 2020. A total of 994 children were screened for malnutrition within that period. For the purpose of our research a total of 277 children were admitted into the study after excluding those who were returnee defaulters and, were younger than 6 months or were older than 59 months. The rest of the children who were well nourished and were not admitted into the study were asked to be attending growth monitoring sessions every 3 months for a period of one year.

\section{Data analysis}

Socio-demographic data of the respondents were collected from their parents/guardians by use of admission entry forms. Anthropometric measurements of the respondents were taken by trained health care workers, in accordance with the Integrated Management of Acute Malnutrition Guideline Handbook ${ }^{2}$, on each visit to the center. Anthropometric parameters were computed from WHO Child Growth Standards ${ }^{11}$ and using WHO AnthroPlus software. For each patient, we calculated their z-score of anthropometric parameters.
Z-score is a classification system to present child nutrition status with no bias due to age of a child.

The following anthropometric parameters were assessed using z-score values:

- weight- WAZ (weight-for-age z-score)...underweight evaluation

- height- HAZ (height for-age z-score)... stunting evaluation

- mid-upper arm circumference- MUAC (MUAC z-score)

- weight-height ratio- WHZ (weight-for-height $\mathrm{z}$-score).... malnutrition evaluation

According to the $\mathrm{WHO}^{11}$, there are these stages of malnutrition based on WHZ z-score:

- optimal nutrition status $>-1$ SD $<1 S D$,

- being at risk of acute malnutrition $>-2$ SD $<-1$ SD,

- moderate acute malnutrition $>-3 \mathrm{SD}<-2 \mathrm{SD}$,

- severe acute malnutrition <- $3 \mathrm{SD}$

when SD is a measure of distance between the child's value and the expected value of the reference population ${ }^{2}$.

In all anthropometric parameters, we followed medians of z-score with interquartile range values. We assessed changes in the values of $\mathrm{z}$ scores on monthly basis - at admission to the program, $1^{\text {st }}, 2^{\text {nd }}, 3^{\text {rd }}$ and $4^{\text {th }}$ months. Kruskal-Wallis test was used to find statistically significant difference in medians of z-scores. We followed the proportion of children with severe malnutrition on a monthly basis by McNemar's test which was used to compare paired proportions before and after an intervention. The level of significance was set to p-value less than 0.05 in statistical software R program 3.4.3 2017.

All data were collected in accordance with the Declaration of Helsinki and international ethical codex.

\section{Results}

The study group consisted of 277 malnourished children (Figure 1); 43\% male and 57\% female. The mean age was 15 months at admission. When following possible factors putting a child into higher risk of malnutrition, we found that $20 \%$ were born of low birthweight; $38 \%$ malnourished children came from a family with 5 and more children; $46 \%$ were with poor family income (less than $1 \$$ per a day per a capita only from casual sources). 
Figure 1: Basic characteristic of children admitted to therapeutic feeding program, $n=277$.

\begin{tabular}{|l|l|}
\hline Sex & $43 \%(118)$ \\
\hline Male & $57 \%(159)$ \\
\hline Female & $15.00 \pm 8.86$ month \\
\hline Age & 12.00 month \\
\hline Mean & 6.00 - 51 month \\
\hline Median & $2.83 \pm 0.55 \mathrm{~kg}$ \\
\hline Range & $2.80 \mathrm{~kg}$ \\
\hline Birthweight & $1.50-4.28 \mathrm{~kg}$ \\
\hline Mean & $80 \%(221)$ \\
\hline Median & $20 \%(56)$ \\
\hline Range & $46 \%(127)$ \\
\hline normal birthweight & $40 \%(112)$ \\
\hline low birthweight & $14 \%(38)$ \\
\hline Household income status per capita \\
\hline poor & \begin{tabular}{l}
$|l|$ \\
\hline Low
\end{tabular} \\
\hline regular income & $46 \%(127)$ \\
\hline Number of children in family \\
\hline 2 children and below & $17 \%(46)$ \\
\hline $3-5$ children & $38 \%(104)$ \\
\hline 5 and more children & \multicolumn{2}{|l|}{} \\
\hline
\end{tabular}

After screening, 64\% children were admitted to the Supplementary Feeding Program with 1 check-up within 14 days; $36 \%$ were admitted to the Outpatient Therapeutic Program with medical check-up needed once in 7 days. RUTF appetite test was done at admission because it is an important indicator of the clinical status of a child. Children who fail the RUTF test mean that they have lost their appetite and can only be managed well in inpatient care. In our study, 19\% of children failed this test and therefore were referred to the sub-county hospital with a therapeutic feeding unit for 7 days. Bilateral pitting edema is a sign of Kwashiorkor, a nutritional disorder caused by inadequate intake of proteins through diets. Edema was present in a total of 67 children; specifically edema grade 1 in 18\%; edema grade 2 in $6 \%$.

Underweight, stunting, wasting and MUAC are essential indicators of children's nutritional status. In our study, we analyzed these indicators by Weight for Age Z Scores (WAZ); Height for Age $\mathrm{Z}$ score (HAZ); MUAC and Weight for Height Z scores (WHZ).

Underweight is a result of multifactorial origin which includes inadequate intake of diet; recurring acute and chronic illnesses with also socio-economic family determinants. Median of WAZ z-score for evaluation of underweight was -2.81 with a range from -5.00 to 1.66 at admission time to our study group.

Stunting is a result of prolonged insufficient nutrition intake and recurring acute infections. In our study at admission time, median of $\mathrm{HAZ}$ zscore was -2.37 with range -5.10 to 1.48 .

MUAC measurements and its cut off points are useful in identifying malnourished children who need urgent treatment due to their elevated risk of dying. Especially it is useful in a community screening and also in a health facility with limited access to equipment and resources. In our study, the mean MUAC was $11.75 \mathrm{~cm}$ with minimum value $7.00 \mathrm{~cm}$ and maximum value $11.10 \mathrm{~cm}$. Median of MUAC z-score was at level -2.47 with a range -4.30 to -0.23 .

Wasting is caused by acute food shortage and chronic illness. It is used in predicting child mortality. In our study, the median WHZ z-score was -2.22 with a range -4.80 to 1.86 . Based on the WHZ z-score classification, in our study there were no children with optimal weight; $30 \%$ were at risk of acute malnutrition; $34 \%$ suffered from moderate acute malnutrition; $36 \%$ by severe acute malnutrition at the time of their admission into the three nutrition center (Figure2).

Figure 2: Anthropometric parameters of children at admission to therapeutic feeding program, $n=277$.

\begin{tabular}{|l|l|}
\hline \multicolumn{2}{|l|}{ Type of nutrition care } \\
\hline SFP & $64 \%(176)$ \\
\hline OTP & $36 \%(101)$ \\
\hline RUTF appetite test \\
\hline+ pass & $81 \%(224)$ \\
\hline - fail & $19 \%(53)$ \\
\hline Presence of bilateral pitting edema \\
\hline No & $76 \%(210)$ \\
\hline body edema + & $18 \%(49)$ \\
\hline body edema ++ & $6 \%(18)$ \\
\hline
\end{tabular}




\begin{tabular}{|c|c|}
\hline \multicolumn{2}{|l|}{ Weight } \\
\hline mean & $7.05 \pm 2.06 \mathrm{~kg}$ \\
\hline median & $6.90 \mathrm{~kg}$ \\
\hline range & $2.80-13.47 \mathrm{~kg}$ \\
\hline \multicolumn{2}{|l|}{ WAZ z-score } \\
\hline Median & -2.81 \\
\hline Range & $-5.00 / 1.66$ \\
\hline \multicolumn{2}{|l|}{ Height } \\
\hline mean & $78.06 \pm 10.42 \mathrm{~cm}$ \\
\hline median & $76.00 \mathrm{~cm}$ \\
\hline range & $63.80-97.47 \mathrm{~cm}$ \\
\hline \multicolumn{2}{|l|}{ HAZ z-score } \\
\hline Median & -2.37 \\
\hline Range & $-5.10 / 1.48$ \\
\hline \multicolumn{2}{|l|}{ MUAC } \\
\hline mean & $10.08 \pm 1.07 \mathrm{~cm}$ \\
\hline median & $10.90 \mathrm{~cm}$ \\
\hline range & $8.50-11.50 \mathrm{~cm}$ \\
\hline \multicolumn{2}{|l|}{ MUAC z-score } \\
\hline Median & -2.47 \\
\hline Range & $-4.30 /-0.23$ \\
\hline \multicolumn{2}{|l|}{ Weight for height } \\
\hline optimal weight & $0 \%(0)$ \\
\hline $\begin{array}{l}\text { being at risk of acute } \\
\text { malnutrition }\end{array}$ & $30 \%(83)$ \\
\hline $\begin{array}{l}\text { moderate acute } \\
\text { malnutrition }\end{array}$ & $34 \%(93)$ \\
\hline $\begin{array}{l}\text { severe acute } \\
\text { malnutrition }\end{array}$ & $36 \%(101)$ \\
\hline \multicolumn{2}{|l|}{ WHZ z-score } \\
\hline Median & -2.22 \\
\hline Range & $-4.80 / 1.86$ \\
\hline
\end{tabular}

We further examined the medians and interquartile ranges of the anthropometric scores of the children from the time they were admitted into the feeding programs up to period of 4 months.

When comparing median values, we found through the Kruskal-Wallis test (Figure3) the following significant differences:

i) there was a statistically significant change in WAZ z-score from admission (median -2.81) to value in $1^{\text {st }}$ month (median -2.14) and also another significant change from $3^{\text {rd }}$ month (median -1.63) to $4^{\text {th }}$ month (median -1.15).

ii) in evaluation of the HAZ z-score, we found significant progress from $1^{\text {st }}$ month value (median -2.13) to $2^{\text {nd }}$ month value (median 1.72 ) and also the progress from $3^{\text {rd }}$ month value (median -1.42 ) to $4^{\text {th }}$ month value (median -1.00).

iii) there was a statistically significant difference of the MUAC $\mathrm{z}$-score median from $1^{\text {st }}$ month $(-2.23)$ to $2^{\text {nd }}$ month $(-1.94)$.

iv) value of the WHZ $\mathrm{Z}$-score significantly change from $1^{\text {st }}$ month (median -1.95) to $2^{\text {nd }}$ month (median -1.48) and $3^{\text {rd }}$ month (median $-1.16)$.

Figure 4 graphically presents progress of anthropometric medians up to the $4^{\text {th }}$ month since the time of admission. Median value of $\mathrm{WHZ} \mathrm{z}_{\mathrm{z}}$ score progressed from -2.22 at admission to -0.71 on the $4^{\text {th }}$ month, which means WHZ changed from moderate acute malnutrition to optimal nutrition status of the 277 respondents in our study. In HAZ z-score, stunting, a progress of median was observed from -2.37 at the point of admission to -1.00 on the $4^{\text {th }}$ month. Medians of WAZ $\mathrm{z}$-score, reflecting underweight, and MUAC zscore changed from -2.81 and -2.47 at admission to -1.15 and -1.68 after 4 -months period.

On monthly basis, we followed proportion of children in the program with median value of WHZ z-score worse than -3. At admission, there were $36 \%$ children with severe acute malnutrition. By using McNemar's test, we found out a significant difference in proportion of children with severe malnutrition at $3^{\text {rd }}$ month, a decrease from $27 \%$ to $23 \%$ and on the $4^{\text {th }}$ month, decrease to $19 \%$ (Figure 5).

\section{Discussion}

Aim of this study was to examine the progression of anthropometric measurements of malnourished children after their admission into the 3 nutrition centers in Kwale County, Kenya. In 2012, the 3 nutrition centers opened their doors for malnourished children, but for purpose of this study, we collected our data from September 2019 to March 2020. In this study, we examined factors that predisposed children to malnutrition in our study location and found that the majority of respondents were: born of low birthweight (20\%); came from families with poor income less than $1 \$$ per a day per a capita only from ca- 
Figure 3: Progress in medians and IQR of anthropometric parameters of children after 4 months in the nutritional program, $n=277$.

\begin{tabular}{|c|c|c|c|c|c|c|}
\hline & Admission & 1st month & 2nd month & 3rd month & 4th month & p-value \\
\hline \multirow{2}{*}{$\begin{array}{l}\text { WAZ } \\
\text { z-score }\end{array}$} & -2.81 & $-2.14^{*}$ & -1.98 & -1.63 & $-1.15^{*}$ & \multirow[t]{2}{*}{0.008} \\
\hline & $-3.75 /-2.23$ & $-2.91 /-1.47$ & $-2.68 /-1.58$ & $-1.97 /-1.28$ & $-1.82 /-0.91$ & \\
\hline \multirow{2}{*}{$\begin{array}{l}\text { HAZ } \\
\text { z-score }\end{array}$} & -2.37 & -2.13 & $-1.72^{*}$ & -1.42 & $-1.00^{*}$ & \multirow[t]{2}{*}{0.013} \\
\hline & $-3.22 /-1.68$ & $-3.11 /-1.65$ & $-2.18 /-1.24$ & $-2.23 /-1.03$ & $-1.69 /-0.42$ & \\
\hline \multirow{2}{*}{$\begin{array}{l}\text { MUAC } \\
\text { z-score }\end{array}$} & -2.47 & -2.23 & $-1.94^{*}$ & -1.82 & -1.68 & \multirow[t]{2}{*}{0.042} \\
\hline & $-3.16 /-1.80$ & $-2.99 /-1.70$ & $-2.55 /-1.46$ & $-2.03 /-1.52$ & $-1.97 /-1.41$ & \\
\hline \multirow{2}{*}{$\begin{array}{l}\text { WHZ } \\
\text { z-score }\end{array}$} & -2.22 & -1.95 & $-1.48^{*}$ & $-1.16^{*}$ & -0.71 & \multirow[t]{2}{*}{0.031} \\
\hline & $-2.78 /-1.46$ & $-2.55 /-1.35$ & $-2.38 /-1.01$ & $-1.80 /-0.83$ & $-1.66 /-0.38$ & \\
\hline
\end{tabular}

${ }^{*}$ Indicating statistically significant difference (p 0.05) of given mean comparing to mean in the previous month by using Kruskal-Wallis test.

Figure 4: Progress in medians of anthropometric parameters of children after 4 months in the nutritional program, $n=277$.

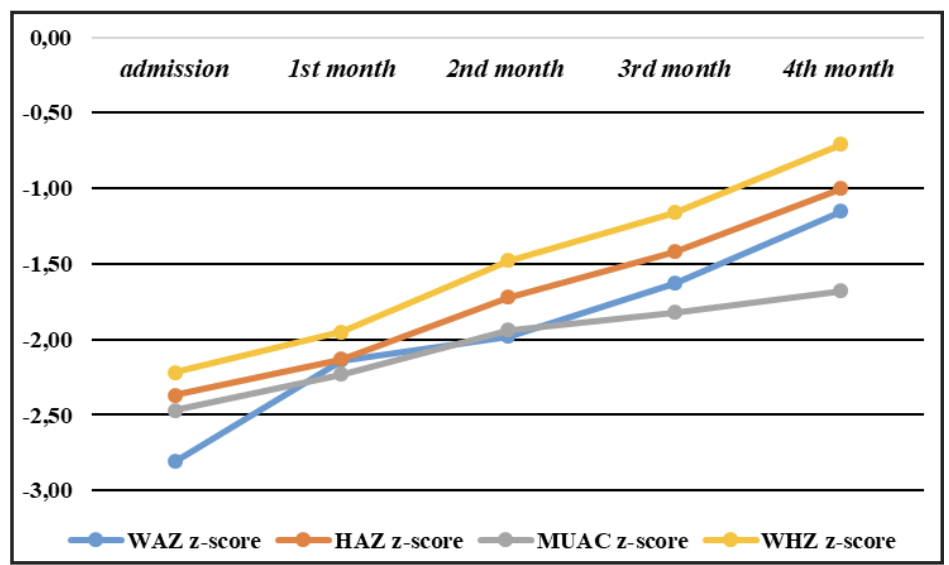

chronic malnutrition, comorbidities and leading into high child mortality ${ }^{13}$.

Socio-economic status of a family is another important determinant of a child nutritional status due to ability of family to provide adequate food intake. Research conducted in Ghana with the objective of finding significant predictors of wasting, stunting and underweight observed that, $63.1 \%$ of malnourished preschool children who were suffering from malnutrition came from families with low sual sources (46\%); family having 3-5 children (46\%). Sengupta-Philip-Benjamin found in their study that $19 \%$ of malnourished cases were born of low birthweight, which was a significant predictor of malnutrition of children under 5 years ${ }^{12}$. According to the WHO, 15-20\% of all births worldwide are of low birthweights. Low birthweight is associated significantly with acute and monthly income ${ }^{14}$. In complex treatment of child malnutrition, it is essential to cover food needs of a child and the whole family. Size of the household is another risk factor that causes malnutrition. The risk of developing malnutrition increases with every additional member to the household. Asfaw et al. (2015) found that almost $60 \%$ of malnourished children below the age of

Figure5: Progress of severe malnutrition proportion cases in children after 4 months in the nutritional program, $\mathrm{n}=277$.

\begin{tabular}{|l|c|c|c|c|c|}
\hline & Admission & 1st Month & 2nd Month & 3rd Month & 4th Month \\
\hline $\begin{array}{l}\text { Severe } \\
\text { malnutrition } \\
\text { WHZ z-score >-3 }\end{array}$ & $36 \%(101)$ & $32 \%(88)$ & $27 \%(77)$ & $23 \%(63)$ & $19 \%(52)$ \\
\hline p-value & & 0.367 & 0.236 & 0.041 & 0.031 \\
\hline
\end{tabular}


5 came from families with 3-5 children who suffered from acute food insecurity even during harvest time ${ }^{15}$.

Weight for Age z-score, denoted by WAZ zscore, is a major indicator of underweight in children. In this study, we observed a statistically significant progress ( $p$-value 0.008 ) in median of WAZ z-score from the point of admission at 2.81 , to -2.14 after the $1^{\text {st }}$ month of treatment and eventually to -1.15 by the end of the $4^{\text {th }}$ month. In 2014, KDHS reported WAZ z-score mean value -0.8 for Kwale County ${ }^{8}$. This difference signifies an increased underweight among children under the age of 5 years in Kwale County between the time the survey was released in 2014 and 2020 when we did this study. This increase can be attributed to acute or chronic illness of children as well as to socio-economic conditions that affect families in Kwale County.

Over the period of this study, the proportion of the HAZ z-score dropped with a p-value 0.013 from -2.37 at admission to -1.00 after 4 months of treatment. Ali et al. identified in his study similar values of the HAZ $\mathrm{z}$-score of mean $\pm \mathrm{SD}$ value $-1.33 \pm 1.2$. There was significant progress (p-value 0.026) of the HAZ z-score after introducing complementary food in nutrition program $^{14}$. MUAC is an important anthropometric tool for assessing nutritional status of children and can be used as a standalone tool for monitoring nutritional recovery ${ }^{16}$. In this study we observed the median of the MUAC z-score progress from the value of -2.47 to -1.68 after 4 months of malnutrition management. The mean of the MUAC z-score in a study realized in Burkina Faso by Goossenes et al. (2012) decreased from -3.3 at the admission to -1.5 at discharging ${ }^{17}$. The most significant change in our study occurred in the WHZ z-score from median value at admission -2.22 to -0.71 after $4^{\text {th }}$ month of nutritional care (p-value 0.031). This finding is similar with study in Burkina Faso (admission mean value 3.4 to discharge mean value -1.5$)^{17}$. This may be due to expected better feeding and childcare practices by educated mothers and caretakers.

Comparison of the mentioned studies with our study pointed out the differences mainly in the MUAC z-score and the WHZ z-score. It can be explained especially by the time mothers introduce complementary foods; types of food for children under 5 included into the nutrition pro- gram; feeding practice of malnourished children; household food insecurity; proper childcare; quality of health care services available to children.

In our study, we found a significant decrease in the prevalence of children suffering from severe acute malnutrition at the admission (101, $36 \%$ ) compared to the prevalence after 4 months in a nutritional care program $(52,19 \%)$. This decrease was statistically significant by McNemar's test (p-value 0.031). Tadesse et al. compared the prevalence of severe acute malnutrition at admission $(28.1 \%)$ and after 4 weeks in nutritional program $(21.6 \%)$. Children with the lowest WHZ (WHZ $<-3$ ) showed a significant change on the average weight gain after 4 weeks of therapy. The largest response was observed among the severely malnourished children ${ }^{18}$. The reason for this significant improvement was due to provision of adequate food supplement in accordance with national guidelines; prompt referral to the hospital in case of emergency; comprehensive community work. We thus conclude that anthropometric measurements of children significantly improve after four months of intensive therapeutic feeding of malnourished children.

There are some limits in our study. First, we did not consider children's comorbidities such as HIV, malaria, diarrhea or tuberculosis on a nutrition status for research intent even though as a part of medical services, we were aware of a child's health status. Second, we did not take into account correlation of rainy season or harvest time which significantly influence food intake in a family. As a third and main limit, 3 nutrition centers have been established within rural health facilities with good infrastructure (geographically easily reachable places for delivery of food supplements from national and international storages). Therefore, our results cannot be interpreted in the same or similar way in less developed regions of Kenya.

\section{Conclusion}

This study concludes that malnourished children below 5 years show significant improvement in their nutritional status when they are admitted into therapeutic feeding programs for a period of at least four months. This improvement corresponds with a proven approach of integrated management of malnutrition where there are interventions at the national/regional level (available health 
center and nutrition center with educated and skilled experts); interventions at community level (for caretakers, family members and communities to provide health and nutrition education, promotion of optimal infant-feeding practices and better childcare); systematic organization of work in a nutrition center (accurate anthropometry measurements, adequate supplementary food for malnourished children under 5as RUTF, porridge, vitamins but also support food for families during child's treatment); home visiting and monitoring of children in their home environment; regular assessment of child nutrition status and creation of the networking among professionals working with malnourished children to share knowledge and experiences and to collaborate if needed. All mentioned areas of intervention are an integral part of comprehensive care approach to successfully treat malnutrition of children under five.

\section{References}

1. WFP \& CDC (2005) A Manual: Measuring and Interpreting Malnutrition and Mortality. Available online: https://www.unscn.org/en/ resource-center/archive/methods-tools-andindicators?idnews $=1473$ (accessed on 2 July, 2020).

2. MINISTRY OF MEDICAL SERVICES \& MINISTRY OF PUBLIC HEALTH AND SANITATION (2010) Handbook Integrated Management of Acute Malnutrition. Kenya: UNICEF.

3. GLOBAL NUTRITION REPORT (2018) Available online: https://globalnutritionreport.org/reports/global-nutrition-report-2018 (accessed 2 July, 2020).

4. DELACEY E et al. (2020) The nutritional status of children living within institutionalized care: a systematic review. In: Peer J, DOI 10.7717/peerj.8484.

5. MORAMARCO S et al. (2018) Filling the Gaps for Enhancing the Effectiveness of Community-Based Programs Combining Treatment and Prevention of Child Malnutrition: Results from the Rainbow Project 20152017 in Zambia. In: International Journal of Environmental Research and Public Health. 2018 Sep; 15(9): 1807. doi: 10.3390/ijerph 15091807

6. UNICEF (2012) Evaluation of Integrated Management of Acute Malnutrition (IMAM).
Kenya Country Case Study. Available online: https://www.unicef.org/evaldatabase/files/Ke nya_CMAM_formatted.pdf (accessed 3 July 2020).

7. DE ONIS M (2000) Measuring nutritional status in relation to mortality. In: Bulletin of WHO, 2000; 78(10):1271-4.

8. KENYA DEMOGRAPHIC AND HEALTH SURVEY (2014) Available online: https:// dhsprogram.com/pubs/pdf/fr308/fr308.pdf (accessed 3 July 2020).

9. NDEMWA M et al. (2017) Nutritional status and association of demographic characteristics with malnutrition among children less than 24 months in Kwale County, Kenya. In: Pan Afr Med J. 2017 Nov 24;28:265. doi: 10.11604/pamj.2017.28.265.12703. eCollection 2017

10. UNICEF (2013) Global Evaluation of Community Management of Acute Malnutrition (CMAM): Global Synthesis Report (link is external). New York: UNICEF.

11. WHO (2006) WHO child growth standards: methods and development: length/height-forage, weight-for-age, weight-for-length, weight-for-height and body mass index-forage. Geneva. Available online: https://www. who.int/childgrowth/standards/technical_report/en/ (accessed 8 July 2020).

12. SENGUPTA P, PHILIP N, BENJAMIN AI (2010) Epidemiological correlates of undernutrition in under - 5 years children in an urban slum of Ludhiana. In: Health and Populations: Perspective and Issues. 2010 vol.33 (1), 1-9.

13. WHO (2014) Global Nutrition Targets 2025: Low birth weight policy brief. Available online: https://www.who.int/nutrition/publications/globaltargets2025_policybrief_lbw/en/ (accessed 20 July 2020).

14. ALI Z et al. (2017) The effect of maternal and child factors on stunting, wasting and underweight among preschool children in Northern Ghana. In: BMC Nutri. 2017; 3:31. Available online: https://www.ncbi.nlm.nih. gov/pmc/articles/PMC7050753/ (accessed 20 July 2020).

15. ASFAW M et al. (2015) Prevalence of undernutrition and associated factors among children aged between six to fifty-nine months in Bule Hora District South Ethiopia. In: BMC 
Public Health. 2015; 15:41. Available online: https://www.ncbi.nlm.nih.gov/pmc/articles/P MC4314803/ (accessed on 20 July 2020).

16. BURRELL A. et al. (2017) Monitoring and discharging children being treated for severe acute malnutrition using mid-upper arm circumference: secondary data analysis from rural Gambia. In: Int Health. 2017 Jul; 9(4): 226-233. Available online: https://www.ncbi. nlm.nih.gov/pmc/articles/PMC5881269/ (accessed on 22 July 2020).

17. GOOSSENES S et al. (2012) Mid-Upper Arm Circumference Based Nutrition Programming: Evidence for a New Approach in Regions with High Burden of Acute Malnutrition. In: PLoS One. 2012; 7(11): e49320. Available online: https://www.ncbi.nlm.nih. gov/pmc/articles/PMC3506602/ (accessed on 22 July 2020).

18. TADESSE A. W. et al. (2017) Choosing Anthropometric Indicators to Monitor the Response to Treatment for Severe Acute Malnutrition in Rural Southern Ethiopia-Empirical Evidence. In: Nutrients. 2017 Dec; 9(12): 1339. Available online: https://www.ncbi. nlm.nih.gov/pmc/articles/PMC5748789/ (accessed on 20 July 2020). 


\title{
Highlands Malaria is Common but HIV very rare in Rural Areas of Burundi 2,000 Meters above Sea Level (Short communication)
}

\author{
G. Ngamygamie (Gaston Ngamygamie)'1, E. Smrekova (Eva Smrekova)1 , V. Krcmery

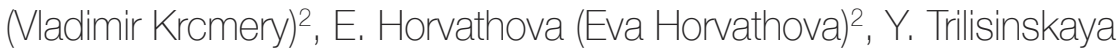 \\ (Yoanna Trilisinskaya) ${ }^{1}$, K. Mulama (Katrina Mulama) ${ }^{1}$
}

${ }^{1}$ Centre de Sante Rumeza \& Hospital of Buraniro, Carmelitan Sisters, joint program with SEU Tropical Institute \& St. Elizabeth University Tropical Program in Republic of Burundi.

${ }^{2}$ Slovak Medical University SZU, Dept. of Tropical Medicine \& Dept. of Public Health \& Alergy Center Vienna West, Vienna, Austria.

\section{E-mail address:}

smrekovaeva@yahoo.fr

\section{Reprint address:}

Eva Smrekova

Centre de Sante Rumeza

Rep of Burundi

Source: Clinical Social Work and Health Intervention

Volume: 12

Issue: 1

Pages: 54 - 55

Cited references: 2

\section{Reviewers:}

M. Johnson Mawole

Mukuru, Nairobi

Vitalis Okoth

School of Public Health University of Hargeisa

\section{Publisher:}

International Society of Applied Preventive Medicine i-gap

\section{Keywords:}

Highlands Malaria HIV.

CSWHI 2021; 12(1): 54 - 55; DOI: 10.22359/cswhi_12_1_11 CC Clinical Social Work and Health Intervention

\section{Abstract:}

Highlands malaria is defined as falciparum parasitaemia at 1,500 meters above sea level nowadays above 2,000 meters. Here we describe the relatively high proportion among outpatients in rural Burundi with a low density of population and travel mobility leading to minimal occurrence of HIV and TB. 


\section{Introduction}

50 years ago, malaria was endemic up to 1,500 $\mathrm{m}$ above sea level, however with urbanization. climate changes and global warming, it is now clinically defined as parasitaemia at an altitude of 2,000 $\mathrm{m}$ above sea level. In the last 5 years, we have described malaria in the rural population of Rwanda at an altitude of 2,500 sea level altitude(1). Vice versa, the proportion of HIV is decreasing in those highlands because climate and the absence of agriculture has decreased the density and contact resulting in a logical decrease in sexually transmitted diseases including HIV(2). This short pilot research showed a decreasing occurrence of HIV in the presence of increasing highlands malaria in the Burundian Region of Rumeza at the altitude of 2,000 m above sea level in 2020 .

\section{Patients and Methods}

A single cohort of outpatient visits within one month at the Rumeza Healthcare Center serving the rural area of about 10,000 people showed 198 visits in the month of October. This clinic is between 1,950 and 2,100 meters above sea level with next nearest hospital is about a 1 hour drive so most of the patients are managed on an outpatient basis.

\section{Results and Discussion}

Malaria was the second commonest disease, surprisingly responsible for up to $30 \%$ of all admissions, just after upper and lower respiratory tract infections (41\%); third commonest disease was gastroenteritis with $19 \%$ of all visits. Parasites were surprisingly found at a much lower proportion than in large cities e.g. Nairobi (2) within a screening for anemia of $7 \%$. Only 4 patients with TB and only 2 patients with HIV positive tests were diagnosed. Low mobility and low density of population were considered responsible for an unexpectedly low occurrence of HIV and $\mathrm{TB}$, vice versa, very surprisingly was a $30 \%$ proportion of fever epidosed with microscopically and repid test-confirmed malaria due to $\mathrm{P}$ falciparum.

\section{Conclusions}

In conclusion, highlands malaria is an emerging public health problem also at altitudes of more than 2,000 meters and stand by therapy spe- cially for children should be included into the first aid equipment available in all villages irrespective of altitude. Our findings are similar to those 5 years ago in Rwanda in the Bigugu Region near the Lake of Kiwu, at an altitude up to 2,500 meters with similar morbidity. Surprisingly, the proportion of HIV was only $1 \%$ and TB $2 \%$ that is much lower than in other Eastern African Union countries such as Uganda, Tanzania and Kenya.

\section{References}

1. MASAN J, SRAMKA M, SABO A, KALATOVA D, ROTTERMUND J, RUZICKY E (2020) The covid-19 disease situation prior to October 2020 in selected countries: the potentially severe consequences of Covid-19 on the nervous system and several key solutions to Covid-19 in relation to digitization and artificial intelligence. In: Acta Misiologica / Bucko Ladislav. - ISBN 2453-7160. - Vol. 14, no. 2 p. 112-126.

2. PERI H A, SUBRAMANIAN S, SLADECKOVA V, BYDZOVSKY J, DURCOVA B, KUBALIKOVA Z, OLAH M, MATULNIKOVA L, DOKTOROV A, BERESOVA A, KUBIK F, FULA M, OTRUBOVA J, KALATOVA D, KUKUCKOVA E, JURINOVA S, BENCA J, SHAHUM A, HOY LEANG HOINAND CHENG HOIN, SETA S/ Early detection of adverse therapy reaction in orphan children with AIDS (short communication) / In: Acta Missiologica. ISSN 1337-7515. - Vol. 13, no. 2 (2019) p. $184-187$. 


\section{Application of Point-of-Care Testing (POCT) in Diagnostics of Influenza during COVID-19 Pandemic in elderly Hospitalized People (Short Communication)}
A. Liptakova (Adriana Liptakova) 1 , M. Dubinova (Martina Dubinova)'1 M. Straka (Marek Straka) $^{1}$, J. Predny (Jan Predny) 1 , A. Longauerova (Andrea Longauerova) ${ }^{1}$, A. Krajcikova (Adriana Krajcikova)' ${ }^{1}$, A. Koscalova (Alena Koscalova)², K. Vlckova $\left(\right.$ Katarina Vlckova) ${ }^{3}$, M. Novotny (Martin Novotny) ${ }^{4}$, P. Jarcuska (Pavol Jarcuska) ${ }^{4}$

${ }^{1}$ Department of Microbiology Medical Faculty Commenius University, Original Article Bratislava, Slovakia.

${ }^{2}$ Department of Infectology and Geographic Medicine Medical Faculty Commenius University, Bratislava, Slovakia.

${ }^{3}$ I. Internal Medicine Department, Medical Faculty Commenius University, Bratislava, Slovakia.

${ }^{4}$ Department of Infectology and Geographic Medicine Medical Faculty P.J. Safarik University Kosice, Slovakia.

\section{E-mail address:}

adriana.liptakova@fmed.uniba.sk

\section{Reprint address:}

Adriana Liptakova

Department of Microbiology, Faculty of Medicine,

Comenius University and University Hospital,

Bratislava

Slovakia

Source: Clinical Social Work and Health Intervention Pages: $56-62$

\section{Reviewers:}

Andrea A Shahum

Chapel Hill NC, USA

Claus Muss

IGAP Zurich $\mathrm{CH}$

\section{Publisher:}

International Society of Applied Preventive Medicine i-gap

\section{Keywords:}

Influenza A/B. POCT. Epidemiological Management. Antiviral Treatment.

CSWHI 2021; 12(1): 56 - 62; DOI: 10.22359/cswhi_12_1_12 (C) Clinical Social Work and Health Intervention

\section{Abstract:}

Influenza is a viral disease of the respiratory tract which affects a relatively large number of people in Slovakia and around the world every year. The patient groups most at risk are the elderly 
and immunocompromised patients in whom the disease can have serious outcomes including death. Therefore, early diagnosis of influenza and subsequent epidemiological management is very important. Point-of-care testing (POCT) seems to be very useful for rapid molecular diagnosis of influenza A and $B$ viruses in patient samples. In today's coronavirus crisis, rapid diagnosis of influenza virus and SARS-CoV-2 in emergency departments in hospitals can streamline triage of patients with symptoms of acute respiratory disease and can reduce the number of hospital-acquired infections.

\section{Editors Note:}

What Happened to Flu Season? on Feb, 25, 2021, Brenda Goodman, MA - WEBMD HEALTH NEWS reported that the U.S. is seeing historically low levels of influenza this season, which started in September 2020. This time last year, the national map of flu activity published by the CDC showed so many active cases that some states had or „very high" activity. This year, Public health labs across the U.S. reported a grand total of 3 cases of flu in the U.S. last week, out of nearly 16,000 samples tested. Clinical laboratories, which tested nearly 25,000 samples, found just 14 flu cases. So far this 2021 season, labs reporting to the CDC had just 1,585 samples test positive for flu of any kind. Compare that to last year over the same period, when there were more than 183,000 positive samples.. Vanderbilt University in Nashville is part of a network of hospitals that are actively looking for flu cases among their patients. They can't find any. This year, only one child has died of the flu. Last year, that number was 195. Why? People are taking precautions for COVID, including masking, social distancing, and frequent hand-washing. More people have taken CDC public health advice to get a flu vaccine. There is just much less human mobility \& travel this year. Children have been out of school $\&$ at home played less with other children.

\section{Introduction}

Influenza is a viral disease of the respiratory tract which affects a relatively large number of people in Slovakia and around the world every year $(1,2,3)$. 164, 883 cases of influenza in $\mathrm{Eu}-$ rope have been reported to the WHO since the beginning of 2020, with influenza A being confirmed in $73 \%$ and influenza B virus in $27 \%$ of cases (4). In the Slovak Republic, 1,470,688 acute respiratory diseases were recorded in the 2018-2019 season, which represents a morbidity of 55,104.9 per 100000 persons in the care of reporting physicians. The highest incidence was recorded in the 19-59-year-old age group. In the 2017-2018 season, 632 samples in total were positive, with influenza A virus confirmed in 567 cases $(89.7 \%)$ and influenza B virus in 65 samples $(10.3 \%)$ (1). In the 2018-2019 season, out of 1,155 samples tested, the influenza A virus was confirmed in 296 cases $(98.9 \%)$ and the influenza $\mathrm{B}$ virus in 3 cases (1.1\%) (5). Those most at risk are the elderly and debilitated patients, in whom the disease can lead to death. Therefore, early diagnosis of influenza and subsequent epidemiological management is very important $(1,6)$.

\section{Pathogenesis of the disease and its clinical forms}

The source of the influenza infection are humans and some animals. As with SARS-CoV-2, the virus is transmitted by aerosol and large droplets (e.g. by sneezing) $(7,8)$. The target organ of influenza virus replication in humans is respiratory tract and the site of virus entry is its mucosa. The incubation period is 18 to 72 hours. The virus begins to spread from the infected individual to the environment 1 day before the onset of the first symptoms and the affected individual is infectious for 5 to 7 days. Initially, the virus causes a local infection of the upper respiratory tract and is found in large amounts in nasopharyngeal secretions. If it spreads to the lower respiratory tract, the infection can cause severe shedding of the bronchial or alveolar epithelium and induce inflammation. Influenza virus infection compromises the mucociliary clearance of the respiratory tract, which promotes the adhesion of bac- 
teria to epithelial cells and the development of bacterial superinfection. Lung tissue damage can lead to hyaline membrane formation, alveolar emphysema, and alveolar wall necrosis. The cellular, interferon, and cytokine response in otherwise healthy individuals is usually sufficient to control the infection and is responsible for the development of systemic symptoms of influenza.

Clinical manifestations of influenza appear suddenly. At the beginning, general symptoms prevail, especially fever, chills, headache, extremity or back muscle pain, nausea and loss of appetite. Severe eye muscle pain and watery and burning eyes can also appear. The overall discomfort lasts on average 3 days, as does the fever. Respiratory problems such as dry cough, inflammation, sore throat and runny nose appear at the onset of the disease. Unlike other upper respiratory tract infections, the most common manifestations of influenza are the general symptoms. In some cases, gastrointestinal symptoms can also appear (7). Similar symptoms are seen in patients infected with the new coronavirus SARS-CoV-2 causing COVID-19 (8). In young, otherwise healthy people, clinical manifestations of the infection can be of varying intensity, from asymptomatic or mild disease to cases with typical influenza symptoms. Complete recovery usually takes 1 to 2 weeks. Severe symptoms and worse course of the disease is observed in high-risk populations - children under 6 months of age, elderly, pregnant women, individuals with chronic respiratory disease, a weakened immune system or on immuno-suppressive treatment. The course of the disease caused by influenza B virus is usually milder compared to influenza A virus $(7,10)$.

\section{Treatment}

In most cases of uncomplicated influenza, symptomatic treatment (bed rest, hydration, vitamin supplementation and antipyretics) is sufficient. Antiviral medications are usually given to patients admitted to hospital, patients with severe or progressive disease course, children younger than 2 years, older persons ( $>65$ years), pregnant women and women up to 2 weeks postpartum. Currently, the most widely used antiviral medications are the neuraminidase inhibitors - oseltamivir and zanamivir. Zanamivir is administered by oral inhalation and oseltamivir is for oral use. Other promising antiviral medications inhibiting viral polymerase, endonuclease, and HA-mediated membrane fusion are under development $(7,11,12)$.

\section{Diagnostics}

Laboratory diagnosis of influenza during acute phase of the disease is based on direct detection of the virus after its isolation in tissue cultures or chicken embryos, or on detection of the viral antigen in the samples from the respiratory tract, or in some cases on a significant increase in specific antiviral antibodies. Nasopharyngeal swab or lavage must be performed within 72 hours after the disease onset, as the amount of virus present decreases rapidly thereafter. The result of virus isolation in tissue cultures may be available within 2 to 6 days. However, these methods are not part of routine microbiological diagnostics. Rapid immunochromatographic assays for antigen detection have relatively low sensitivity and specificity. Indirect diagnostic methods can help determine the diagnosis only during recovery phase based on a comparison of the titer of antibodies in paired serum samples taken several days or up to 2 weeks apart.

Currently, the real-time polymerase chain reaction (real-time PCR) is considered to be the most reliable laboratory diagnostic method for influenza A and B viruses $(7,13,14)$. Point-ofcare testing (POCT) appears to be very useful for rapid molecular detection of influenza $\mathrm{A}$ and $\mathrm{B}$ viruses in patient samples. These tests have a high analytical sensitivity and specificity in comparison with other methods used in diagnostic virology (viral culture, direct detection of antigen in swab samples, serology testing), and the samples can be tested immediately after collection (15). The early diagnosis of influenza enables quick isolation of infected individuals and early initiation of antiviral treatment in patients with complications and prevents the influenza spread and overprescription of antibiotics.

\section{Materials and methods}

The patients were diagnosed from October 2019 to May 2020, that means during the usual flu season and during the COVID-19 pandemic. Nasopharyngeal swabs were collected as clinical material from 89 patients with suspected influenza. POCT testing was ordered in patients with symptoms of acute respiratory disease and per- 
formed during patient examination in the emergency room of the 1st Department of Internal Medicine at the University Hospital Bratislava and in the emergency room of the Department of Infectology and Travel Medicine, Faculty of Medicine, Pavel Jozef Šafárik University, at Louis Pasteur University Hospital (UNLP) in Košice. Most patients were elderly.

The collected samples were placed in a universal transport medium and immediately analyzed (no transport or storage). Detection of the influenza virus in the samples was performed using the cobas ${ }^{\circledR}$ Influenza A/B Assay on a cobas ${ }^{\circledR}$ Liat $^{\circledR}$ System (Roche Molecular Systems, Pleasanton, California, USA). The assay uses multiplex real-time RT-PCR for detection. The viral RNA is reversely transcribed into complementary DNA, amplified, and its quantity is subsequently evaluated using fluorescent signals. The instrument is fully automated and the test takes only a few minutes. The results are available in approximately 20 minutes. The assay is not intended for serial testing (15).

\section{Results}

At the University Hospital Bratislava, the influenza A virus was detected in $9(13 \%)$ patients, and the influenza B virus in $7(10 \%)$ patients. The remaining $53(77 \%)$ patients were negative. Most persons tested were male - $42(61 \%)$. Of these, 11 were positive ( 6 had influenza A, 5 influenza B). Of the 27 (39\%) women tested, 5 were positive (3 had influenza A, 2 influenza B). The average age of patients diagnosed with influenza $A$ or B was 60 years. After clinical evaluation, 6 patients with the confirmed disease were transferred to the Department of Infectology and Geographical Medicine, Faculty of Medicine, SZU and UNB, where they were isolated and where 5 of these patients received antiviral treatment (Oseltamivir, Tamiflu ${ }^{\circledR}$ ) (tab. 1).

At UNLP in Košice, 20 patients were tested, and influenza was confirmed in 3 patients (15\%), influenza A in two men (10\%) (78 and 48 years old) and influenza B in 1 woman (31 years old). The results were also confirmed in the National Reference Center (NRC) for influenza. Samples from 10 patients were sent to the NRC for influenza and in all cases, the results were in concordance with our findings - 7 negative and 3 positive results (influenza A was confirmed in 2 cases
Figure 2: Proportion of influenza positive cases in patients with suspected influenza from UN Bratislava and UNLP Košice (influenza A 13\%, influenza B 10\%, negative $77 \%$, samples cannot be tested 3\%).

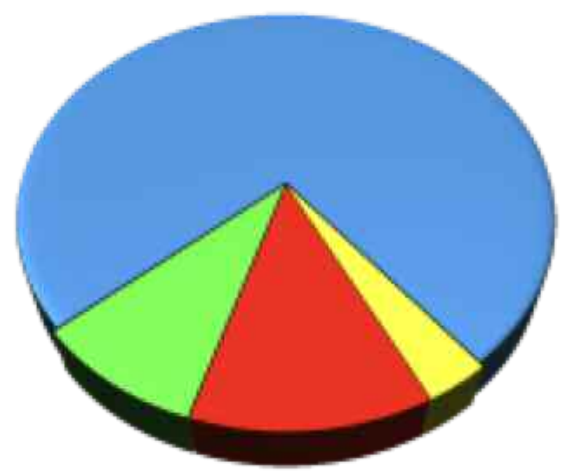

Influenza A Influenza B Negative

Samples cannot be tested

and influenza B in 1 case). In three cases, the samples could not be analyzed, but in 1 case, the patient sample was transported in other than recommended transport medium. The proportion of diagnosed and confirmed patients from both sites is shown in Figure 2.

\section{Discussion and conclusions}

Influenza is a viral respiratory disease with the highest prevalence during the winter and spring months (8). Rapid POCT molecular tests appear to be appropriate for its early diagnosis and subsequent proper clinical and epidemiological management. They can distinguish influenza A from influenza B virus and their results are available within 20 minutes after sample collection, which represents a very significant progress in clinical virological diagnostics (15). POCT testing is ideal for patient triage during an epidemic and allows to initiate appropriate treatment almost immediately after patient's admission, and/or to implement preventive anti-epidemic measures immediately after the patient's initial examination. If the influenza virus is detected in the collected sample material by POCT, the same nasal and/or nasopharyngeal swab sample can be sent for virus isolation to NRC for influ- 
Table 1: Characteristics of hospitalized patients with confirmed influenza A or B

\begin{tabular}{|c|c|c|c|c|}
\hline $\begin{array}{l}\text { Patient } \\
\text { gender } \\
\text { and age }\end{array}$ & Comorbidities & $\begin{array}{l}\text { Administered } \\
\text { medications }\end{array}$ & Outcome & $\begin{array}{l}\text { Length of } \\
\text { hospitalization }\end{array}$ \\
\hline $\begin{array}{l}\text { Male, } \\
40 \text { years } \\
\text { old }\end{array}$ & $\begin{array}{l}\text { Influenza ABacterial } \\
\text { tracheobronchitisSevere } \\
\text { bronchial asthma }\end{array}$ & $\begin{array}{l}\text { Oseltamivir }\left(\text { Tamiflu }^{\circledR}\right) \\
\text { Ceftriaxone }\end{array}$ & $\begin{array}{l}\text { Discharged } \\
\text { from the hospi- } \\
\text { tal to home } \\
\text { care in a good } \\
\text { health condi- } \\
\text { tion }\end{array}$ & 4 days \\
\hline $\begin{array}{l}\text { Female, } \\
86 \text { years } \\
\text { old }\end{array}$ & $\begin{array}{l}\text { Influenza A with hypox- } \\
\text { emic-hypercapnic respira- } \\
\text { tory failure Sepsis caused } \\
\text { by Staphylococcus aureus } \\
\text { secondary pneumonia } \\
\text { Acute cystitis caused by } \\
\text { Escherichia coliPersistent } \\
\text { atrial fibrillation with } \\
\text { rapid ventricular respon- } \\
\text { seChronic ischemic heart } \\
\text { disease, unspecifiedAcute } \\
\text { decompensated chronic } \\
\text { left ventricular heart fail- } \\
\text { ure }\end{array}$ & $\begin{array}{l}\left.\text { Oseltamivir (Tamiflu }{ }^{\circledR}\right) \\
\text { Ceftriaxone } \\
\text { LinezolidClarithromy- } \\
\mathrm{CinO}_{2} \\
\\
\end{array}$ & $\begin{array}{l}\text { Cardiology re- } \\
\text { ferral to the 5th } \\
\text { Department of } \\
\text { Internal } \\
\text { Medicine, Fac- } \\
\text { ulty of } \\
\text { Medicine, UK } \\
\text { and UNB in } \\
\text { Bratislava Ruži- } \\
\text { nov }\end{array}$ & 13 days \\
\hline $\begin{array}{l}\text { Male, } 40 \\
\text { years old }\end{array}$ & $\begin{array}{l}\text { Influenza AMild hypona- } \\
\text { tremiaDehydrationArte- } \\
\text { rial hypertension }\end{array}$ & $\begin{array}{l}\text { Oseltamivir } \\
\left(\text { Tamiflu }^{\circledR}\right)\end{array}$ & \begin{tabular}{l|} 
Discharged \\
from the hospi- \\
tal to home \\
care in a good \\
health condi- \\
tion
\end{tabular} & 11 days \\
\hline $\begin{array}{l}\text { Female, } \\
85 \text { years } \\
\text { old }\end{array}$ & $\begin{array}{l}\text { Influenza AArterial hyper- } \\
\text { tension grade } 2 \\
\text { (ESC/ESH) with very high } \\
\text { CV risklschemic heart dis- } \\
\text { ease with angina pectoris } \\
\text { and heart failure }\end{array}$ & ClarithromycinO ${ }_{2}$ & $\begin{array}{l}\text { Discharged } \\
\text { from the hospi- } \\
\text { tal to home } \\
\text { care in an im- } \\
\text { proved health } \\
\text { condition }\end{array}$ & 5 days \\
\hline $\begin{array}{l}\text { Male, } 64 \\
\text { years old }\end{array}$ & $\begin{array}{l}\text { Influenza B Bilateral } \\
\text { bronchopneumonia pre- } \\
\text { dominantly involving the } \\
\text { lung bases COPDArterial } \\
\text { hypertension grade } 2 \\
\text { (ESH/ESC) with high CV } \\
\text { risk }\end{array}$ & $\begin{array}{l}\text { Oseltamivir }\left(\text { Tamiflu }^{\circledR}\right) \\
\text { CeftriaxoneO }_{2}\end{array}$ & $\begin{array}{l}\text { Discharged } \\
\text { from the hospi- } \\
\text { tal to home } \\
\text { care in an im- } \\
\text { proved health } \\
\text { condition }\end{array}$ & 7 days \\
\hline
\end{tabular}




\begin{tabular}{|c|c|c|c|c|}
\hline $\begin{array}{l}\text { Male, } 58 \\
\text { years old }\end{array}$ & $\begin{array}{l}\text { Influenza A } \\
\text { Bronchopneumonia } \\
\text { involving the right lung } \\
\text { New onset paroxysmal } \\
\text { atrial fibrillation with } \\
\text { normal ventricular } \\
\text { response, CHA2DS2- } \\
\text { VASc score 3, HAS-BLED } \\
\text { score } 1 \\
\text { Chronic left ventricular } \\
\text { heart failure with re- } \\
\text { duced ejection fraction } \\
\text { (37\%) }\end{array}$ & $\begin{array}{l}\text { Oseltamivir } \\
\text { (Tamiflu }^{\circledR} \text { ) } \\
\text { Ceftriaxone } \\
\mathrm{O}_{2}\end{array}$ & $\begin{array}{l}\text { Discharged } \\
\text { from the hospi- } \\
\text { tal to home } \\
\text { care in an im- } \\
\text { proved health } \\
\text { condition }\end{array}$ & 6 days \\
\hline $\begin{array}{l}\text { Male, } 79 \\
\text { years old }\end{array}$ & $\begin{array}{l}\text { Influenza A } \\
\text { Bilateral interstitial } \\
\text { pneumonia } \\
\text { Arterial hypertension } \\
\text { grade } 2 \text { (ESH/ESC) with } \\
\text { high CV risk } \\
\text { Type } 2 \text { diabetes }\end{array}$ & $\begin{array}{l}\text { Oseltamivir } \\
\left(\text { Tamiflu }^{\circledR}\right) \\
\text { Cefotaxime } \\
\text { Clarithromycin } \\
\mathrm{O}_{2}\end{array}$ & $\begin{array}{l}\text { Discharged } \\
\text { from the De- } \\
\text { partment of } \\
\text { Pneumology } \\
\text { UNLP to home } \\
\text { care in an im- } \\
\text { proved health } \\
\text { condition }\end{array}$ & 7 days \\
\hline $\begin{array}{l}\text { Male, } 48 \\
\text { years old }\end{array}$ & $\begin{array}{l}\text { Influenza A } \\
\text { Obesity } \\
\text { Arterial hypertension } \\
\text { grade } 1 \text { (ESH/ESC) with } \\
\text { high CV risk, treated by } \\
\text { beta-blockers }\end{array}$ & $\begin{array}{l}\text { Oseltamivir } \\
\text { (Tamiflu }^{\circledR} \text { ) } \\
\text { Clarithromycin } \\
\mathrm{O}_{2}\end{array}$ & $\begin{array}{l}\text { Discharged } \\
\text { from the hospi- } \\
\text { tal to home } \\
\text { care in an im- } \\
\text { proved health } \\
\text { condition }\end{array}$ & 7 days \\
\hline $\begin{array}{l}\text { Female, } \\
31 \text { years } \\
\text { old }\end{array}$ & $\begin{array}{l}\text { Influenza B } \\
\text { No comorbidities } \\
\text { Returned from China }\end{array}$ & $\begin{array}{l}\text { Oseltamivir } \\
\left(\text { Tamiflu }^{\circledR}\right)\end{array}$ & $\begin{array}{l}\text { Discharged } \\
\text { from the hospi- } \\
\text { tal to home } \\
\text { care in a good } \\
\text { health condi- } \\
\text { tion }\end{array}$ & 3 days \\
\hline
\end{tabular}

enza as a part of comprehensive diagnostics recommended by the WHO in its current strategy (16).

Although the group of our patients was relatively small ( 89 patients) and testing was also affected by the onset of the COVID-19 pandemic, the results are interesting - up to $22 \%$ of the analyzed samples (19 in total) were positive. The high ratio of detected influenza $B$ virus strains to influenza A strains (8 to 11) was also interesting. In contrast, in the 2018-2019 season, the ratio of influenza B cases to influenza A cases in the group of samples tested by Regional Public Health Authorities in the Slovak Republic was 3 to 296 (5).

Influenza A or B was confirmed in 16 patients of the group examined at the 1st Department of Internal Medicine LF UK and UNB. Thanks to the rapid POCT diagnostics, it was possible to prevent the spread of influenza in the medical facilities, the health of other patients was not put at risk, and the patients could receive antiviral medications.

The introduction of POCT testing for in- 
fluenza A and B at both sites was clearly a great benefit in the diagnosis of acute respiratory diseases and was also relatively simple, fast, and reliable thanks to the chosen testing platform. The introduction of rapid diagnostics for influenza and in the future possibly for SARS-CoV-2 at the hospital emergency departments will significantly improve the triage of patients with symptoms of respiratory infection and minimize the risk of hospital-acquired infections.*

*Conflict of interests: The authors have no conflict of interests.

\section{References}

1. THE SLOVAK NATIONAL PUBLIC HEALTH AUTHORITY (2019) Evaluation of annual influenza season and vaccination rate 2018/2019. https://www.cdc.gov/flu/about/k eyfacts.htm. https://www.who.int/en/newsroom/fact-sheets/detail/influenza-(seasonal). https://www.ecdc.europa.eu/en/publicationsdata/influenza-virus-characterisation-summary- europe-june-2020

2. THE SLOVAK NATIONAL PUBLIC HEALTH AUTHORITY (2020) Annual evaluation of National Reference Centres in 2019.

3. TAUBENBERGER J K, MORENS D M (2006) 1918 Influenza: the mother of all pandemics. Emerging Infectious Diseases,: 1522.

4. LIPTAKOVAA. et al. (2019) Medical Microbiology. Bratislava: Herba s. r. o.

5. LIPTAKOVA A., DUBINOVA M (2020) Coronoaviruses - should we be afraid of? Medical Horizon, 69 (3): 70-72.

6. MURRAY P R, ROSENTHAL K S, PFALLER M A (2013) Medical Microbiology. 7th ed. Elsevier Saunders, http://www.cdc.gov/ swineflu/index.htm. http://www.cdc.gov/ swineflu/recommendations.htm.

7. UYEKI T M, BERNSTEIN H H, BRADLEY J S, et al. (2019) Clinical Practice Guidelines by the Infectious Diseases Society of America: 2018 Update on Diagnosis, Treatment, Chemoprophylaxis, and Institutional Outbreak Management of Seasonal Influenza. Clin Infect Dis, 68(6): 895-902.
8. SASINKA M, HRUSOVSKY S (2009) INFLUENZA A, Medical Horizon, 5 http:// www.cdc.gov/flu/professionals/diagnosis/rapidlab.htm.

9. CHEN L, TIAN Y, CHEN S, LIESENFELD O (2015) Performance of the Cobas(®) Influenza A/B Assay for Rapid Pcr-Based Detection of Influenza Compared to Prodesse ProFlu+ and Viral Culture. Eur J Microbiological Immunology (Bp), 5(4): 236-245. https://www.who.int/news-room/detail/1103-2019-who-launches-new-global-influenza-strategy. 


\section{Alleviation of Refugee Crisis in Lebanon through Humanitarian Aid Projects of Slovak Development Organizations in the Era of Covid-19 Pandemic}

\section{B. Markovic Baluchova (Bozena Markovic Baluchova)}

${ }^{1}$ Department of Development and Environmental Studies, Faculty of Science,

Original Article Palacky University in Olomouc, U1. 17. listopadu 12, 77146 Olomouc,

Czech Republic.

${ }^{2}$ Ambrela - Platform for Development Organizations, Mileticova 7, 82108 Bratislava, Slovakia.

\section{E-mail address:}

boba.baluchova@gmail.com

\section{Reviewers:}

Andrea A Shahum

Chapel Hill NC, USA

Claus Muss

IGAP Zurich $\mathrm{CH}$

\section{Reprint address:}

Bozena Markovic Baluchova

Department of Development and Environmental Studies, Faculty of Science

Palacky University in Olomouc,

Ul. 17. listopadu 12

77146 Olomouc

Czech Republic

Source: Clinical Social Work and Health Intervention

Volume: 12

Issue: 1

Pages: $63-68$

Cited references: 14

\section{Publisher:}

International Society of Applied Preventive Medicine i-gap

\section{Keywords:}

Humanitarian Aid. SlovakAid. ODA. Lebanon. Refugees. Migration. Covid-19 Pandemic. Ambrela

- Platform for Development Organizations.

CSWHI 2021; 12(1): 63 - 68; DOI: 10.22359/cswhi_12_1_13 CC Clinical Social Work and Health Intervention

\section{Abstract:}

Lebanon hosts the highest number of refugees in the world in relation to its population (every seventh inhabitant is a refugee). In light of the events of Spring 2020, new concerns emerge: how will the living conditions of the domestic and refugee communities in Lebanon, already burdened by the economic crisis, be exacerbated by the Covid-19 pandemic? In this paper, the Slovak intervention by members of Ambrela - Plat- 
form for Development Organizations is presented. It focuses on preventing and addressing the causes of migration by improving the living conditions of the population and its prospects for finding employment in home communities. Study also shows the impact on alleviation of the refugee crisis in Lebanon under the SlovakAid brand by the recent humanitarian crisis related to the Covid-19.

\section{Introduction}

Currently, the small Middle Eastern country of Lebanon with its population of 6.8 million (World Population Review, 2020) is experiencing a political, financial and refugee crisis all at the same time. It is home to around one million refugees displaced by the war in nearby Syria, lasting since 2011. If we add up hundreds of thousands of Palestinian refugees displaced from society, who have been traveling to the country since 1948 until this day, the number may increase significantly (Markovic Baluchova, 2020). This small country on the Mediterranean coast, where Shiites, Sunnis and Christians share power, still has the highest number of refugees per capita in the world (UNHCR, 2020). Lebanon, tried by the 19751990 civil war and the wars with Israel (1982 \& 2006), has not collapsed nor disintegrated. Still, the Spring hunger strikes impacted by the Covid19 pandemic may further deepen the internal disintegration and collapse of the state.

The problems associated with the refugee crisis are not manageable in the long run. The growing number of refugees from Syria is a heavy burden, especially for Lebanon's infrastructure and labor market. This is an issue especially in the Bekaa Valley, where more than 300,000 refugees live. Due to the legal vacuum, many fleeing people end up in the infamous Palestinian refugee camps of Sabra and Shatila in Beirut. Families in need live there in inhospitable conditions. There is dirty water close by the tents, garbage heaps, no sewerage, the roads are dusty, and electricity is expensive (Toda, 2016).

The European Union and its member states (including Slovakia) work to assist the Lebanese government in addressing the above-mentioned crises. One of the EU's strategies to deal with the refugee crisis and the growing number of people fleeing from the Middle East and
North Africa into Europe is to help the countries most affected by the crisis and closest to its epicenter. Lebanon may serve as an instance of what such aid looks like in practice. Since the outbreak of the so-called migration and refugee crisis, the Slovak Republic has been intensively involved in humanitarian activities in Lebanon. It has been focusing on preventing and addressing the causes of migration by improving the living conditions of the population and its prospects for finding employment in home communities. Special attention has been paid to improving the living conditions of refugees with an aim to assist them in their temporary stay in host countries, or their return to their countries of origin. (SlovakAid, 2019) Since 2016, the Slovak Republic has been implementing humanitarian projects there through official development assistance (ODA). The Slovak Agency for International Development Cooperation (SAIDC) has supported 9 humanitarian projects in Lebanon under the brand of SlovakAid so far.

\section{Methodology and Research Participants}

The aim of the paper is to identify activities of Slovak organizations alleviating the refugee crisis in Lebanon and to analyse an impact of global pandemic Covid-19 on these activities as part of ongoing Humanitarian Aid projects. Qualitative research methods (content analysis of project documents, as well as nonprofits' websites and following structured interviews with project managers from particular aid nonprofits) have been chosen for validation.

First research participant was ADRA Slovakia - a Slovak humanitarian and development organization which operates in low-income countries and at home. It is part of the international organization ADRA (Adventist Development and Relief Agency), and in 2018 it 
celebrated 25 years of its existence. From August 2019 to August 2020, in cooperation with the partner ADRA Lebanon, the organization implemented a project in the field of WASH (i.e. water, sanitation and hygiene) entitled, WASH Intervention in the Baalbek Area for Syrian refugees and the Lebanese (ADRA Slovakia, 2019).

The organization People in Need (PiN) also took an active part in the research and Ambrela's Case Study (Markovic Baluchova, 2020). It just finished its third project in Lebanon. The history of the organization dates back to 1999 when it was established in response to the situation in war-torn Kosovo. In 2016, PiN merged with Czech humanitarian and development organization People in Need, and today it operates as a non-profit organization as a part of the international People in Need network. From August 2019 to the end of August 2020, the organization was implementing a project entitled Education as a Pathway to Better Living Conditions for Vulnerable Children and Youth From Lebanese and Refugee Communities in Tripoli (People in Need, 2019) in the second largest city in Lebanon.

The medical humanitarian organization Magna was established in 2001 and started providing medical assistance to disaster victims around the world based on the direct experience of the founding couple with the AIDS epidemic in Cambodia. Today, through its hospitals, Magna provides health care, medicines and food to children and their families. It has its own medical and technical teams in the field, which provide the necessary help and treatment. Since October 2019, the organization has been implementing a project in Lebanon titled, Providing Reproductive Health Care, Including the Management of Cases of Sexual Violence, to Syrian Refugees and Internally Displaced Persons in the Baalbek-Hermel Areas (Magna, 2019), scheduled for completion in November 2020.

Another Ambrela member, Caritas Slovakia, assists more than 23,000 people in need each year through 10 diocesan/archdiocesan charities and its secretariat in Slovakia and abroad. In low-income countries, the organization implements its humanitarian and development projects - sometimes with the support of
SlovakAid, but more often thanks to the funding by private donors, church collections or with the support of the Conference of Bishops of Slovakia (CBS). The project titled, Supporting Education of Children of Palestinian Refugees is implemented thanks to the support of CBS for several years now. The activities take place in the Dbayeh Refugee Camp near Beirut, which was established in 1959 for the Palestinian community fleeing the armed conflict in Galilee. Currently, a fourth generation lives in the camp, making their living from casual work. However, during the civil war in Lebanon, the local school was destroyed and the children attended schools close by the camp. They were often harassed and attacked while commuting to school (Caritas Slovakia, 2019).

\section{Results}

Lebanon was already in a serious economic crisis before the onset of the COVID-19 pandemic, which has exacerbated it further. The Lebanese population is losing not only employment but also savings. A new wave of protests against anti-pandemic measures has risen. While the Autumn 2019 street protests against the ruling elites were peaceful, those of March 2020 seemed different and more dangerous (Daniel, 2020).

In March 2020, after the Covid-19 outbreak, Ambrela member organizations which implement humanitarian and development projects in the country had to reduce their activities and transform and adapt them significantly to the then current situation. The content analysis of documents and interviews with project managers from particular Slovak aid nonprofits were conducted from June to July 2020 - just a few weeks before the massive explosion of ammonium nitrate in Beirut port. Therefore, an aid intervention of Ambrela's members to this humanitarian crisis is not included into this research paper.

The main output of the ADRA's project was the construction of a water reservoir in Hay El Shaab Wal Zahrae within Baalbek. The aim was to ensure access to safe drinking water for the local community (21,000 Lebanese and 8,000 Syrian people). According to the latest information, the construction of the water reservoir was 
completed, but ADRA had to halt or suspend training on safe and hygienic use of water for locals in Baalbek. The activities were being transformed into training focused on hygiene and Covid-19 prevention. Before the COVID19 pandemic, only one such training was held in a camp for 25 families, which was attended mainly by women. Project manager AnnaMaria Benkova of ADRA Slovakia stated:

„The training participants expressed gratitude for the acquired knowledge and skills, but also for our interest in providing a helping hand and education which will translate into the care of their families. They also offered something like a needs assessment and ideas for future projects on how to improve living conditions with a bit of assistance.“

The PiN's project responded to the educational needs of children aged 4-10 to qualify for enrollment and maintain their regular school attendance. It also targeted young people, helping to increase the employability of the disadvantaged youth aged 16-26. Through field workers, in cooperation with the SEED partner, the project provided psychosocial support to children, young people, their families, as well as pedagogical staff. It also educated parents to support the educational environment for their offsprings: which then led to better school results; good habits and stronger motivation to learn. The project was positively received by local religious, ethnic and culturally diverse communities, which resulted in improved educational opportunities and livelihoods.

During the project implementation, the organization encountered obstacles which needed to be addressed and perceived as challenges. Project manager Viola Ternenyova from PiN stated that the biggest obstacle was the deepening socio-economic crisis in Lebanon:

„All essential products and services were highly expensive, families prioritized livelihoods over education, and the banking system ceased to function. The Lebanese currency was unsustainable and foreign currencies were unavailable. In practice, this meant difficulties in financing projects as well as in performing simple tasks. Nervousness and tension in society were growing, and the level of violence was rising.
The field work was extremely demanding, but at the same time, very instructive."

The organization People in Need provided education and psychological support through WhatsApp during the lockdown due to Covid19 pandemic. Moreover, it provided cell phone top-up credit for families who could not afford the Internet. It also started providing multifunctional meal tickets for families who could no longer afford to buy even basic food and hygiene products. Importantly, the organization also coordinated its activities with the activities of other organizations (People in Need, 2020).

The Magna's project provides needy and socially excluded people with access to health care, and strengthens the capacities of health structures and local staff to access and treat cases of sexual violence. Strengthening the professional capacities and raising awareness of promoting the rights of women and other groups of active civil society is equally important. The Chaat, Youmine and Baalbek refugee settlements in the Baalbek-Hermel area still do not provide quality reproductive health services, either mental health and psychosocial support for victims of sexual violence. In the Spring 2020 Magna adapted its activities to the current situation related to Covid-19 pandemic. The health and psychosocial support to refugee women address the current phase of the crisis, while there is an assumption that sexual violence may increase during the Covid-19 pandemic.

The project of Caritas Slovakia covers the costs associated with private transport for the children from economically weakest families in order to provide them with an opportunity to gain an education. In addition to transport, the project also provides them with school supplies, material equipment, and tutoring (Caritas Slovakia, 2019). Alena Horvathova from Caritas Slovakia explains:

„Thanks to the provision of school supplies, school fees, footwear, clothing, tutoring and transport, children from the poorest families of the Palestinian refugee community are able to attend school activities. Hence, they have hope for a better future than their parents, thus preventing the emergence of the so-called lost generation." Caritas also adapted their activities to the 
current situation related to the COVID-19 pandemic.

\section{Conclusion}

Economists believe that $50 \%$ of the Lebanese population already lives in poverty without a state social support network (Daniel 2020). Up to $95 \%$ of Syrian and Palestinian refugees are dependent on financial assistance. The country is in real danger of famine. Due to Covid-19 pandemic food prices have risen dramatically once again, with many people having lost their employment due to restrictions on movement and workplace closures. (Chehayeb, \& Sewell, 2020) Sufficient social isolation and maintaining a safe distance is not possible in the overcrowded refugee communities. The situation is the worst for those who live in tent settlements and therefore do not even have access to running water. The massive explosion of ammonium nitrate in Beirut port from August 2020 subsequently deepened the humanitarian crisis.

New project was supposed to start in Summer 2020 under the name Basic health care and nutrition program for refugees from Dbayeh camp in Beirut, implemented by St. Elizabeth University of Health and Social Work and supported by SlovakAid. The project aims to improve the health of refugees, especially from Syria. It may also be challenged by the current situation related to Covid-19 pandemic, as well as the aftermath of Beirut's deadly explosion.

Interviews by Slovak journalists (Toda, 2016), development field workers and development volunteers (Markovic Baluchova, 2020; People in Need, 2020) with refugees in Lebanon show that, most of all, they now need employment to provide livelihoods for their families. If possible, many of them would like to return home to Syria in the future. However, until it is safe and doable, Lebanon will need much help. All of the above-mentioned SlovakAid projects are contributing to the solution despite the current Covid-19 pandemic barriers and challenges.

\section{References}

1. ADRA SLOVAKIA (2019) A Source of Drinking Water for a Village in Lebanon [In Slovak language]. Available online: https://www.adra.sk/libanonrezervoar/.
2. CARITAS SLOVAKIA (2019) Projects in Lebanon [In Slovak language]. Available online: https://charita.sk/pomoc-utecencom/ nase-projekty/projekty-v-libanone/.

3. CHEHAYEB K, SEWELL A (2020) How COVID-19 Is Limiting Healthcare Access for Rugees in Lebanon. Available online: https://www.thenewhumanitarian.org/feature/2020/04/21/Lebanon-coronavirusrefugee-healthcare.

4. DANIEL J (2020) When Banks Burn. The Lebanese Revolution Between the Coronavirus and Economic Collapse [In Czech language]. Available online: https:// a2larm.cz/2020/05/kdyz-hori-banky-

libanonska-revoluce-mezi-koronavirem-aekonomickym-kolapsem/.

5. MAGNA (2019) Where We Help Lebanon. [In Slovak language]. Available online: https://www.magna.org/sk/kdepomahame/libanon/.

6. MARKOVIC BALUCHOVA B (2020) Examples of Humanitarian Aid Projects of Slovak Organizations in Lebanon (Case study). Available online: https://ambrela.org /wp- content/uploads/2020/07/Ambrela_ se_Study_Humanitarian_Aid_projects_Lib anon_2020.pdf.

7. MARKOVIC BALUCHOVA B (2020) [In Slovak language]. Available online: https:// mediaaboutdevelopment.wordpress.com/20 20/05/09/dobrovolnicka-anna-hrubonovatvarou-migracie/.

8. PEOPLE IN NEED (2019) Humanitarian Aid-Lebanon. [In Slovak language]. Available online: https://clovekvohrozeni.sk/humanitarna-pomoc/libanon/.

9. PEOPLE IN NEED (2020) Coronavirus and Our Projects Abroad [In Slovak language]. Available online: https://clovek vohrozeni.sk/koronavirus-a-nase-projektyv-zahranici/

10. PEOPLE IN NEED (2020) Estelle, a Humanitarian Worker in Lebanon: I Do Not Regret Taking the Last Flight [In Slovak language]. Available online: (https://clovek vohrozeni.sk/humanitarna-pracovnicka-vlibanone-rozhovor/.

11. SLOVAK AID (2019) Partner Countries and Regions - Middle East [In Slovak language]. Available online: https://www.slo- 
vakaid.sk/sk/ako-pomahame/partnerske-regiony-krajiny.

12. TODA M (2016) It Has the Highest Number of Refugees per Capita. We Looked into How the Small Country of Lebanon Can Survive [In Slovak language]. Available online: https://dennikn.sk/500403/ma-utecencov-cela-europa-sa-pozriet-moze-malylibanon-prezit/.

13. UNHCR (2020) Global Trends 2019. Available online: https://www.unhcr.org/globaltrends2019 .

14. WORLD POPULATION REVIEW (2020) Lebanon Population 2020. Available online: https://worldpopulationreview.com/ countries/lebanon-population/.

This paper (and conducted research) is a part of project entitled 'SDGs and Migration' implemented by Slovak Platform for development organizations - Ambrela within the framework of the DEAR programme. 


\section{Financial Literacy as one of the Professional Competencies of Social Workers to Prevent or Solve Socio-economic Problems}

\section{J. Pavelkova (Jaroslava Pavelkova)}

${ }^{1}$ Department of Health Care Sciences, Faculty of Humanities, Tomas Bata

University in Zlin, Czech Republic.

\section{E-mail address:}

jpavelkova@utb.cz

\section{Reviewers:}

Claus Muss

IGAP Zurich $\mathrm{CH}$

Jarmila Holkova

Malindi

\section{Reprint address:}

Jaroslava Pavelkova

Tomas Bata University in Zlin

Faculty of Humanities, Department of Health Care Sciences

Stefanikova 5670

76001 Zlin

Czech Republic

Source: Clinical Social Work and Health Intervention

Pages: $69-74$

Volume: 12

Issue: 1

\section{Publisher:}

International Society of Applied Preventive Medicine i-gap

\section{Keywords:}

Social work. Social worker. Client. Financial Literacy. Professional Competence. Socio-economic Problem.

CSWHI 2021; 12(1): 69 - 74; DOI: 10.22359/cswhi_12_1_14 (C) Clinical Social Work and Health Intervention

\section{Abstract:}

This paper deals with the issue of financial literacy as one of the professional competencies of social workers to prevent or solve socio-economic problems of clients. A practical example is presented of resolving the financial problems of a client of a non-profit social organization, a homeless shelter in the Czech Republic. Through knowledge and experience in financial literacy issues, the educated social worker is able to determine the extent and causes of material need persuade the client to cooperate, as well as mobilize him toward alleviating or eliminating his unfavorable financial situation. 


\section{Introduction}

Despite the many cautions given to the whole of today's society, more and more individuals find themselves in an unfavorable socio-economic situation due to socio-economic problems they have caused themselves or have been unable to prevent. Low economic and financial literacy manifests itself without distinction among all target social groups with the exception of young children. Typically, financial problems are caused by, e.g.: the loss of a job; imprisonment; breakdown of a marriage; loss of a partner; death of a family member; loss of housing; as well as the aforementioned low financial literacy. Frivolous decisions to purchase uncertified financial products from banks or non-banking institutions can bring an individual into debt, which may in turn cause him and his family, and thus the overall community, to fall into a state of poverty. Within various social service institutions, social workers regularly face problems in their activities with clients whom they attempt to address by helping individuals; families as well as communities develop socio-economic competences regarding financial management.

\section{The current situation in the Czech Republic regarding mortgage foreclosures}

The financial literacy of the Czech population remains unsatisfactory. Ten\% of Czech citizens face debt-related problems. Although the number of seizures is decreasing, the number is still huge. According to the Chamber of Executors in 2018, about 770,000 people were involved, with the total number of foreclosures at 4.54 million (Biben 2019). Based on information from Haba's Map of Seizures in 2017, 9.7\% of Czechs, i.e. 863,000 , had been a party to one or more foreclosures. Compared to 2016, this number has increased by more than 29,000 , with 493,000 people having been involved in 3 or more of these procedures. 151,000 people had participated in more than 10 foreclosures at this time (for a total of 4.67 million procedures in all). Last year for the first time, more mortgages were ended in the Czech Republic then were begun. Executors launched more than half a million new mortgages in 2018, but closed 35,000 more. On the other hand, the number of newly launched seizures in 2018 has fallen year by year by 106,000 , to
505,000 , and the figure has been decreasing for several years in a row. The number of completed foreclosures has been growing for a long time, with 540,000 last year (Biben, 2019). As reported by Mecirova (2018), the largest increase in foreclosures was recorded in the regions of Karlovy Vary $(10.2 \%)$, Usti nad Labem (8.8\%) and Central Bohemia (5.5\%), while the absolute worst situations could be found for the inhabitants in the cities of Usti nad Labem (21.9\%) and Most $(21.0 \%)$. The negative development of over-indebtedness in these regions was influenced mainly by debt cycling to pay off a standing debt. The average age of a Czech borrower is 44 years, but despite information interventions, every year the number of foreclosures against seniors in the Czech Republic has increased $(61,000$ persons aged 65+).

\section{Financial literacy}

Financial literacy is a collection of knowledge, skills, attitudes and values that a person needs to financially secure himself and his family in today's society and to actively engage in the market for financial products and services. A financially literate citizen focuses on money and price issues, and is able to responsibly manage a personal or family budget, including managing financial assets and financial liabilities in the face of changing life situations. As stated in the Financial Literacy Primer (2011), financial literacy is a special subsection of broader economic literacy which also includes, for example, the ability to secure income; to consider the implications of personal decisions for present and future income; orientation in the job market; the ability to make decisions regarding expenses; etc.

\section{Socio-economically disadvantaged groups}

A person's socio-economic portfolio often affects his position in society. In addition to other influences, economic disparities are determined by the fact that groups living in less favorable conditions have different approaches to education, quality of housing, meals, leisure, etc. Disadvantaged groups of the population consist of those that are challenged by debilities and disabilities which place them outside the normal life of society. The process by which an individual or an entire group of people is impeded or com- 
pletely denied access to resources, jobs and opportunities that enable participation in the social, economic and political activities of mainstream society (socio-economic decline) is termed social expulsion/social exclusion (Schavel et al. 2012). These groups include, e.g.: the long-term unemployed; unemployed young people; members of ethnic minorities and migrants; senior citizens; persons with disabilities or health conditions; persons with long-term or unmanageable debt; those with limited marketable skills; people for whom living on social benefits has become a way of life; persons with various kinds of addictions; children living in vulnerable families, i.e. with dysfunctional, poor, unemployed or multiple sets of parents; or in families with a history of violence (these children often receive a lower level of education, impaired health as well as fewer opportunities and incentives toward social development); persons living in disadvantaged areas with high unemployment, low quality housing, poor transport services, etc.; persons released from prison; as well as mothers on parental leave and single mothers.

The risk of social exclusion increases in an individual who accumulates the above-mentioned hindrances, such as the long-term unemployed with low qualifications living in a disadvantaged area. Financial problems with concomitant over-indebtedness accelerate their exclusion from the ordinary life of the society to its margins, with a return to normalcy quite difficult. Social exclusion threatens those groups of people who have a weakened bond to at least 1 of the 3 integrated integration levels of society (Matel et al. 2011).

\section{Socio-economic competences of social workers}

The concept of socio-economic competence includes financial literacy (i.e. monetary, information and budget literacy) as well as other soft skills (i.e. communication and presentation skills that lead to increased success in the labor market). The absence and importance of these soft competences is highlighted by Nova (2017), who points out how employment support services are not sufficiently linked to social services. The problem is the lack of one-on-one work with the client in terms of the individual being able to present himself and communicate adequately, as well as the low continuity regarding retraining for a particular job. All of these deficiencies can decrease the efficiency of the tools used by social workers to help their clients secure employment.

If a person falls into a debt trap, i.e. a situation in which the repayment of one or more loans is resolved by taking out an additional loan, or if a lien is taken out on his home or other vital assets, it becomes more advantageous for him to reduce his legal income from which the repayment is calculated to a minimum, and for him to move his activities into the black economy. Social workers in various institutions are experiencing increased demands in terms of social and specialized counseling in the area of economic problems (Pavelkova 2018). The current financial crisis has brought out an even greater need for financial education focusing on the practical skills associated with managing a personal or family budget which are a prerequisite for the financial security of individuals and families. Financial education aims to work responsibly in terms of both personal and family finances with the goal of preventing the indebtedness of citizens and households.

\section{Social work with clients in a difficult financial situation}

According to Schavel et al. (2012), financial instability in families is currently a widespread problem and is considered one of the most important factors regarding secondary crises in families. Issues include: the total cost of household expenses; the levels of education achieved; the age of the main breadwinner; along with a potential increase in the number of household members who are economically active and can support the economic stability of the family. In particular, the unemployment of a family member; the necessity of working for minimum wage; finding only precarious work; working abroad may cause economic instability, a condition which is associated with other problems such as family debt and the inability to handle money. These circumstances frequently occur within single-parent families or in families led by single mothers, dependent on their own income and/or state aid in the form of benefits and allowances. The cause of the problems may also lie with the debtor, i.e.:

purchasing too many unnecessary goods and services; the non-payment of rent or mandatory 
fees; but also. from fees related to transportation and commuting, etc. (Pavelkova 2018). Members of the family may also contribute to the problems by assuming their own heavy liabilities; incurring compounded debt; indulging in socio-pathological addictions; as well as through mental immaturity and the inability to take control of their own life.

Disadvantaged individuals and families suffering from socio-economic problems are often unable or unwilling to help themselves. In these cases, it is necessary to use the help of an educated social worker working within a state or non-state institution which is ready to contribute to the resolution of the unfavorable financial situation of the individual and his family. In general, the prevention of socio-economic instability can be characterized by ensuring compliance and consistency by means of (Pavelkova 2013):

- National statutory regulations and measures, e.g. inspecting the activities of commercial entities, etc.

- The acceptance of ethics and moral values regulated by legal norms and their interpretation by commercial entities in the society.

- Cooperation with the media in raising public awareness of these issues.

- Well-prepared teachers carrying out their important role (educational institutions).

- The educated social worker, who is of the greatest importance and who must possess a predetermined set of skills, abilities, knowledge as well as certain personal qualities. This professional should be an expert in the social work sector and be knowledgeable about financial literacy, thus can contribute to improving problematic situations, in this case in the area of financial instability issues (social counseling, not only at the basic level but also at an advanced expert level to address the client's needs which are potentially in conflict with society).

- Prevention, lifelong learning, spiritual and ecclesiastical activities.

In terms of content, the social counseling to be offered is aimed at determining the extent of the nature and causes of material need (Schavel, Olah 2010, p. 68-69). This means that in the initial phases of engagement with the client the social counselor first focuses on identifying the primary causes of debt (using the basic prevailing social counseling methods). Through the professional's knowledge and experience; by using communication skills; a social counselor must develop a collaborative relationship with the client and mobilize him towards cooperation in dealing with the client's adverse situation. In working with the client, the counselor ensures that relevant information is readily available including expert advice from specialists, e.g. psychologists, doctors, clergy, attorneys and financial advisors. The counselor offers suggestions for addressing, directing and supporting the client as well as helping locate possible resources to help effectively correct the client's socio-economic problems. As mentioned above, these steps consist mainly of content frameworks of counseling with a focus on reducing the existent debts of the family; teaching members to manage situations at the present time; avoiding the creation of new debts; creating optimal conditions to strengthen the social ties of family members; along with engaging all family members in upcoming changes and procedures for dealing with the unfavorable financial reality.

Certain mechanisms within the state social system can be used, i.e. networks of social entities which fall within local jurisdictions that allow the use of social loans; one-off social assistance; etc. At the level of state administration in the area of social affairs, benefits are available for immediate material need as well as in the form of state social support funding (e.g. for a child at pre-school and school age in the form of subsidies, school supplies, motivational allowances, etc.). It is also possible to elicit help from civic associations that specialize in these issues and are able to provide clients with longterm assistance that complements the support mechanisms of other entities; one example being the Citizens Advice Centers in the Czech Republic. 39 of these centers are currently in existence; in addition to offering free legal advice, these institutions also provide financial advice as well as engage in other related activities with those in need (Association of Citizens Advice, 2019).

\section{Example of financial consulting with a client residing in a homeless shelter}

The provision of social services is governed by the Standards of Quality of Social Services contained in addendum No. 2 to the Decree of the 
Ministry of Labor and Social Affairs, No. 505/2006 Coll., which is an implementation regulation to Act No. 108/2006 Coll., . One of the law's goals, such as is the case with shelters in the Czech Republic, is to operate a network of community services aimed, inter alia, at those socially excluded or otherwise disadvantaged or at risk. This group also explicitly includes homeless women. The target group of the facilities is women aged 18 and over in an unfavorable social situation associated with the loss of a home or housing that they are unable to resolve on their own. This negative social situation can include cases of: insecure or unsatisfactory housing; unemployment; relationship problems;, lack of resources for everyday life; the suppression of fundamental rights and freedoms, the return from imprisonment or other institutional care, as well as the lack of basic skills necessary for everyday life. Work with clients can be divided into several activities, each of which can, however, also intersect with and influence each other. In our case, it is essential, for example, to provide operational advice on carrying out administrative and legal procedures (e.g. requests for obtaining appropriate social benefits, loss of documents, etc.). But the primary function is to provide important consultation services including assistance in the resolution of specific client problems in the area of debt, foreclosures, insolvency, etc. Here again, the importance of basic knowledge of the educated social worker regarding the provisions of financial literacy information to clients again comes to the fore. The following is an example of the successful resolution of the unfavorable financial situation of a client living in a homeless shelter.

\section{Case analysis}

A 25-year-old client, S. L., came to the shelter when she was released from the psychiatric ward for treatment for substance addiction. During the time she was living on the streets, she had no insight into her financial situation because of her substance dependency, and her debts to various parties had compounded. In 2014, the client borrowed 5 books from the library that she did not return and which she later lost as she was living in a squat.

Her debt in late fees to the library began to increase, and when the court decided that she should pay the large sum of 12,000 CZK (468 EUR) to the library, the client began to seek advice from a social worker.

Together the client and the social worker contacted the library to ascertain all of the information regarding the client's debt. After hearing the client's story, the library's legal department considered the situation, and a solution was offered. In situations when a social worker and a client are able to demonstrate the circumstances of such a case, the library's legal department has the option of lowering the debt upon agreement with the library director, even if a court decision regarding the matter has already been rendered. With the help of a social worker, the client catalogued her social situation in writing, describing the time she lived homeless on the street and succumbed to addiction, and thus fell into a state during which she was unable to control her actions and behavior.

The client and the social worker provided evidence of the following:

- Confirmation of regular attendance at a counseling center that deals with treatment for addiction.

- Confirmation of attendance at a low-threshold treatment facility while she was living on the street.

- Confirmation from the Labor Office of the Czech Republic that she is receiving material need benefit payments, and in what amount.

- Confirmation of hospitalization in the psychiatric ward of a hospital.

- Discharge report from the psychiatric ward.

- Rental agreement contract with the shelter.

The client was interested in resolving her financial situation, i.e. the debt she had incurred. All the pertinent information was documented in writing and sent to the library's legal department with the help of a social worker. Within one week, the client received information that the debt had been reduced by 10,000 CZK, leaving the client only with the calculated debt for the purchase of the books and the court fee, which came to only 2,000 CZK (78 EUR). The client agreed with the library on a payment schedule in which each month, she was to pay at least 100 CZK (4 EUR) at any library branch. In cooperation with the social worker, the client's active approach to solving her economic and social situation was encouraged. 


\section{Conclusion}

Significant indebtedness and the consequent inability to repay debts along with the ensuing enforcement proceedings is affecting increasing numbers of people, with no target social group excluded. One possibility to resolve and prevent financial uncertainty in people in contemporary society is the use of professionally trained social workers, who on the basis of their socio-economic competences can determine the extent and causes of a client's material need; open up avenues of cooperation for the client; finally, mobilize the client's financial and other resources to mitigate the unfavorable financial situation and often eliminate it altogether.

\section{References}

1. ARTICLE IN AN ONLINE PERIODICAL (2019) The Association of Citizens Advice (2019) [online] [cit. 2019-06-18]. Available from: https://www.obcanskeporadny.cz/en/ (Czech).

2. ARTICLE IN AN ONLINE PERIODICAL (2019) BIBEN M (2019) Current Data for 2018: New executions have decreased, but it is still half a million per year. Aktualne. cz. [online] [cit. 2019-06-19]. Available from: https://zpravy.aktualne.cz/domaci/novychexekuci-loni-ubylo-stale-je-to-ale-pul-milionu-za rok/r 380083b440f011e98a200cc47ab 5f122/(Czech).

3. TEAM AUTHORS (2011) The Financial Literacy Primer. Prague. Cofet. 416 p. (Czech).

4. MATEL A et al. (2011) Applied Social Pathology in Social Work. Bratislava. College of Health and Social Work of St. Elizabeth. 267 p. (Slovak).

5. ARTICLE IN AN ONLINE PERIODICAL (2018) MECIROVA L (2018) The number of executions in the Czech Republic increased in 2018. Finance.cz [online] [cit. 2019-0618]. Available from: http://www.finance.cz/ 505009-exekuce-v-cesku-2018/(Czech).

6. NOVA M (2017) Poverty and Social Exclusion as a Social Problem. In: Vansac P, Barkasi D, Popovicova M, Editors. Community care in helping professions. Proceedings of International Conference; Warsawa: Wyższa Szkoła Finansów i Zarządzania w Warszawie. p. 174-178. (Czech).

7. PAVELKOVA J (2013) Social and Educa- tional Context of Financial Literacy. In: Socio-economic and Humanities Studies. ISSN 1804-6800. Vol. 3, No 1, p. 62-65. (Czech).

8. PAVELKOVA J (2018) Practical Using Social-economic Competencies of Social Workers to Eliminate the Socio-economic Problems of the Client. In: Suvada J, Gallova A, Editors. The role of health and social work in today's society. Proceedings of International Conference; Rimavské Janovce: Association for Social Development and Citizens Support Slovak Republic. p. 427-439. (Czech).

9. SCHAVEL M et al. (2012) Social Work with Families with Socio-economic Problems. In: Pavelkova J, Preuss K, Editors. Social and Educational Context of Financial Literacy. Prague: Banking Institute College. p. 43-50. (Slovak).

10. SCHAVEL M, OLAH M (2010) Social counselling and communication. Bratislava. College of Health and Social Work of St. Elizabeth. 218 p. (Slovak).

11. STANDARDS OF QUALITY OF SOCIAL SERVICES, ANNEX NO. 2 (2006) Of the Decree of the Ministry of Labor and Social Affairs of the Czech Republic, No. 505/2006 Coll., Implementing regulation to Act No. 108/2006 Coll., On Social Services. (Czech). 
No. 1, Vol. 12, 2021

Editor-in-chief: Peter G. Fedor-Freybergh

\section{CLINICAL SOCIAL WORK AND HEALTH INTERVENTION}

\section{Indexed by:}

Web of Science/ESCI

ERIH

Alexander Street

ProQuest

ScienceOpen

Ulrich's

CrossRef Similarity Check Powered by iThenticate

Journal DOI 10.22359/cswhi

Issue DOI 10.22359/cswhi_12_1 